\title{
The effect of contemporary approaches education on prospective teachers' self efficacy towards science teaching and technological pedagogical content knowledge self confidence
}

\author{
Ümmühan Ormancı ${ }^{* a}$, Sevinç Kaçar ${ }^{* * b}$, Erkan Özcan ${ }^{* * * c}$, Ali Günay Balım ${ }^{* * * * c}$ \\ ${ }^{a}$ Bursa Uludağ University, Faculty of Education, Bursa/Turkey \\ ${ }^{\mathrm{b}}$ Cyprus International University, Faculty of Education, Nicosia/KKTC \\ ${ }^{c}$ Dokuz Eylül University, Faculty of Education, Izmir/Turkey
}

Article Info

DOI: $10.31704 /$ ijocis.2020.001

Article History:

Received 20 August 2019

Revised $\quad 30$ October 2019

Accepted 05 June 2020

Online $\quad 08$ June 2020

Keywords:

Science education,

contemporary approaches,

self-efficacy, TPACK.

Article Type:

Research paper

\begin{abstract}
It was aimed to investigate the effect of teacher candidates' self-efficacy towards science teaching and technological pedagogical content knowledge on their self-confidence. In this study, pre-experimental design method was used. Thirty prospective science teachers from different universities participated. The trainings were given by faculty members and continued for eight days. Two different scales were used as data collection tools. While there was no significant difference in self efficacy towards science teaching scores of prospective science teachers of contemporary approaches education, there was a significant difference in TPACK self confidence in favor of post-test. It is considered that more importance should be given to the integration of technology during university education.
\end{abstract}

\section{Çağdaş yaklaşımlar eğitiminin öğretmen adaylarının fen öğretimine yönelik öz yeterliklerine ve teknolojik pedagojik alan bilgisi öz güvenlerine etkisi}

\begin{tabular}{|c|c|}
\hline \multicolumn{2}{|c|}{ DOI: 10.31704/ijocis.2020.001 } \\
\hline \multicolumn{2}{|c|}{ Makale Geçmişi: } \\
\hline Geliş & 20 Ağustos 2019 \\
\hline Düzeltme & 30 Ekim 2019 \\
\hline Kabul & 5 Haziran 2020 \\
\hline Çevrimiçi & 8 Haziran 2020 \\
\hline \multicolumn{2}{|c|}{ Anahtar Kelimeler: } \\
\hline \multicolumn{2}{|c|}{$\begin{array}{l}\text { Fen eğitimi, öz yeterlik, } \\
\text { çağdaş yaklaşımlar, TPAB. }\end{array}$} \\
\hline Makale Tü & \\
\hline
\end{tabular}

Öz

Bu çalışmada öğretmen adaylarına çağdaş yaklaşımlar eğitimi verilmiş ve bu eğitimin öğretmen adaylarının fen öğretimine yönelik öz yeterliklerine ve teknolojik pedagojik alan bilgileri öz güvenlerine etkisinin araştırılması amaçlanmıştır. Bu çalışmada basit deneysel desen kullanılmıştır. Çalışmaya farklı üniversitelerde öğrenim gören 30 fen bilgisi öğretmen adayı katılmıştır. Eğitimler öğretim üyeleri tarafından verilmiş ve sekiz gün devam etmiştir. Veri toplama aracı iki farklı ölçek kullanılmıştır. Sonuçta, çağdaş yaklaşımlar eğitiminin fen bilgisi öğretmen adaylarının fen öğretimine yönelik öz yeterlik puanlarında anlamlı bir farklılık olmazken, TPAB öz güvenlerinde son-test lehine anlamlı bir farklılık olduğu anlaşılmıştır. Üniversite eğitimi boyunca teknoloji entegrasyonuna önem verilmesi gerektiği düşünülmektedir.

\footnotetext{
* Author: ummuhan45@gmail.com

** Author: kacarsevinc@gmail.com

*** Author: erkanozcan88@gmail.com

**** Author: agunay.balim@deu.edu.tr
}

Orcid ID: https://orcid.org/0000-0003-3669-4537

Orcid ID: https://orcid.org/0000-0003-4288-592X

Orcid ID: https://orcid.org/0000-0002-8579-6233

Orcid ID: https://orcid.org/0000-0003-2010-1696 


\section{Introduction}

Science teaching is an important discipline for individuals to notice the events and phenomena that occur in their lives and in nature and to evaluate these events and/or phenomena scientifically. The main objective of the science course is to ensure that students become individuals who know themselves and their environment, who can find solutions to the problems they face, who can think critically, creatively, etc. In parallel with this situation, the Ministry of National Education (MoNE) (2018) stated that curricula have been prepared to help educate individuals who can produce and use information, solve problems, and have skills like critical thinking, entrepreneurship, and communication. For this purpose, it is aimed to educate individuals with science literacy in science programs. In our country and in many other countries (USA, UK, Singapore, etc.), the vision of science curriculum is determined as educating science literate individuals. Scientifically literate individuals are expected to have basic knowledge of science (biology, physics, chemistry, earth, environmental sciences, science and engineering applications) and scientific process skills to explore the natural environment (MoNE, 2013; 2018). In this context, being individuals with high-level thinking skills and being able to use knowledge in their daily lives is directly related to science literacy, which is the basic vision of science programs.

Countries are developing science education programs or changing their existing programs in line with the requirements of the era. In the second half of the twentieth century, changes happened in the understanding of the growth and development of knowledge (Duschl \& Osborne, 2002) and this was reflected in the curricula. Considering that we are in the information age, it should be ensured that students gain the skills of accessing information rather than transferring the existing information to them (Duran, 2016). In parallel with this situation, countries have started to adopt the teaching approach that shifts from behaviorism to constructivism by changing their curriculum (Güneş, Sağdıç, \& Şimşek, 2018). In parallel, the science curriculum of our country has been prepared in accordance with many new methods such as inquiry-based learning, argumentation-based learning, and STEM education. The inquiry-based learning approach aims to educate science literate individuals (Duran, 2015). In addition, as Sever and Güven (2012) stated, because inquiry-based learning aims to acquire skills such as being independent and lifelong learning individuals, reading graphics, problem solving, creative and critical thinking, and science literacy largely overlaps with the characteristics expected from individuals. At this point, argumentation-based science learning is another approach that stands out in terms of skills necessary for educating literate individuals (Duran, Doruk, \& Kaplan, 2017). Finally, STEM, which started to be studied in international literature in the 90 's and in our country for the last four years (Herdem \& Ünal, 2018), has started to be expressed effectively in science programs. Turkish Industry and Business Association (TUSIAD, 2017) stated that in order to unlock the potential of Turkey's young population, STEM infrastructure should be acquired and for this purpose, a workforce with creative, interdisciplinary thinking, information and communication skills should be created. As it can be understood, the need for STEM education and skills is due to the change in the global economy and labor requirements (Kennedy \& Odell, 2014). In this context, both due to the nature of science and for the development of countries, the importance of contemporary approaches, especially STEM education, in educating individuals with the necessary skills is revealed.

Teachers and prospective teachers have big duties in order to educate scientifically literate individuals. The ability of teachers to be effective and successful in their branches depends on how well their pre-service training is (Azar, 2011). Teachers are expected to be well-educated individuals first in order to successfully carry out their roles (Kavas \& Bugay, 2009). In this respect, in order to educate students with the necessary skills, teachers need to know contemporary approaches and apply them effectively. When the literature is examined, inquiry-based learning cannot be applied at the expected level due to the traditional beliefs and practices of teachers (Duran \& Dökme, 2018). The situation is also similar for argumentation and STEM training. Bakırcl and Kutlu (2018) state that there is a need for teachers who have STEM education in sufficient number and quality. In this context, it is necessary to carry out studies that will change the perspectives of teachers and prospective teachers 
on practical approaches, provide the necessary resources for the implementation, and encourage the participation of teachers in such studies (Yıldırır \& Nakiboğlu, 2014).

The importance of the courses and courses given to teachers during their undergraduate education becomes evident. At this point, although it is based on contemporary approaches (such as STEM, inquiry-based learning) in primary science programs, it can be stated that these methods are not effectively processed in universities' faculties of education or there are differences from university to university. However, with the "Undergraduate Program of Science Education (2018)" which was implemented in 2018, it can be said that this situation has gone in a more positive direction and the number of courses for science education has increased. Within the scope of the program, "Approaches to Teaching and Learning Science", "Middle School Science Curricula", "Methods of Science Teaching 1", "Methods of Science Teaching 2" courses are included in science teaching. Looking at the content of these courses, there are many topics and it is stated that the approaches/methods used in science education should be included. Only within the scope of "Methods of Science Teaching 2" course, the approaches and methods expressed in the primary education program and expressed within the scope of this study are included. In addition to these methods, it is aimed to provide students with many approaches and methods and skills. In this context, it can be stated that an average of one weekly course hours can be allocated to these approaches within the scope of the course. However, given that prospective teachers are asked to process their science courses in parallel with these approaches in the future, it is clear that this time will not be enough. As can be understood, within the scope of the science teaching program, it can be stated that the methods and techniques included in the primary education program are included in different course contents but there are no courses, compulsory or optional, focusing only on these methods. At this point, the importance of a course or training to be created for the approaches in the science curriculum is emerging. Because it is thought that the trainings that will introduce contemporary approaches and show how they can be applied in science courses are of great importance for prospective teachers. It is thought that it is important to inform prospective teachers about these approaches and methods, to raise awareness and to make them into practitioners before starting the teaching profession.

In this study, prospective science teachers were given contemporary approaches education and the effectiveness of the education on prospective teachers was investigated. One of the variables chosen for this purpose is self-efficacy towards science teaching. The teacher's belief in self-proficiency is the belief to show the necessary behaviors in order to successfully implement the teaching task (Yener, Aydin, \& Köklü, 2012). Self-efficacy in science education is associated with the beliefs of science teachers and of prospective teachers about science teaching and classroom activities (Yaman, Cansüngü Koray, \& Altunçekiç, 2004). Teachers and prospective teachers are expected to have beliefs and skills to effectively process science by using these approaches so that they can apply constructivist philosophy-based approaches such as STEM, argumentation-based learning, and inquiry-based learning. In this context, it is thought that as the prospective teachers increase their knowledge and experience towards these approaches, they will be able to teach science better and their self-efficacy towards science teaching will be high. In order to teach science effectively, teachers are expected to have high self-efficacy in science teaching. As Yurdatapan (2013) notes, when teaching approaches in which students are active are used, individuals who feel confident and adequate can be raised. In parallel with this situation, the effect of contemporary approaches education on prospective teachers' self-efficacy towards science teaching was investigated.

Another variable selected within the scope of the study is the self-confidence in Technological Pedagogical and Content Knowledge (TPACK). All approaches within the scope of the training are directly related to TPACK. At this point, it is thought that the trainings conducted for these approaches will have positive results in the self-confidence of prospective teachers regarding TPACK. In addition, TPACK is among the important knowledge for teachers of the future (Korucu, Usta, \& Atun, 2017) and it is thought that all teachers should benefit from their TPACK in their profession (Balçın \& Ergün, 2019). 
In parallel with this situation, it was found appropriate to choose TPACK self-confidence of prospective teachers. As can be understood, two variables which are closely related to both the teaching profession and contemporary approaches have been selected. In this study, it was aimed to investigate the effect of contemporary approaches education on prospective teachers' self-efficacy towards science teaching and self-confidence of Technological Pedagogical and Content Knowledge (TPACK). In parallel with this aim, the research questions of the study are as follows:

1. Is there a significant difference between self-efficacy pre-test and post-test scores of science teacher candidates who are trained in contemporary approaches?

2. Is there a significant difference between self-confidence towards Technological Pedagogical and Content Knowledge (TPACK) pre-test and post-test scores of prospective science teachers who are trained in contemporary approaches?

\section{Theoretical Framework}

\section{Inquiry-Based Learning}

While inquiry-based learning is a constructivist approach, it is a method that allows learners to configure concepts by taking advantage of verbal interaction and experience (Schmid, 2015). Inquirybased learning can be likened to scientific investigations of interest in a parallel way to the work of scientists (Capps \& Crawford, 2013). Throughout the process, students work like scientists and try to structure information by conducting relevant research. As Tan and Tan (2014) stated, inquiry-based learning aims to develop students as active learners who own their learning. In research-inquiry based learning, individuals are responsible for their own learning in parallel to being actively involved in the process. Parallel to this situation, self-efficacy towards learning is positively affected by inquiry-based learning.

In the process of Inquiry-Based Learning, students often work with problems of daily life that reflect complex and nonlinear processes (Şaşmaz-Ören, Ormancı, Babacan, Çiçek, \& Koparan, 2010; Werner, 2007). In addition, this process helps to understand scientific concepts, as it allows for participating and practicing activities similar to the study processes of scientists (Apedoe, Walker, \& Reeves, 2006). As it can be understood, students have an active role in the research-inquiry process and their learning develops in a positive way. Also, interrogation-based learning arouses curiosity and interest in students (Spronken-Smith, Bullard, Ray, Roberts, \& Keiffer, 2008). This increases students' interest in the course and enables them to participate more effectively in the process. Consequently, when an inquiry-based learning approach is applied, as Duran and Dökme (2018) states, students are active throughout the process, growing up as individuals who use their scientific process skills and develop their thinking skills by conducting discussions and activities.

In the research-inquiry process, students engage in scientific thinking processes and various activities in order to produce new information (Abdi, 2014). Students are empowered to become independentfree learners (Gibson, 1998), move out of the role of passive listeners and act as active participants (Tatar, 2006). The teacher is actively involved as a guide in this process. In parallel with this situation, the application and understanding of scientific concepts and methods rather than memorizing scientific facts and knowledge is at the forefront of inquiry-based learning (Bell, Urhahne, Schanze, \& Ploetzner, 2010).

Parallel to the developments in technology, the integration of technology into the course content and process has begun to come to the fore. In parallel, as Edelson, Gordin and Pea (1999) noted, computer and network technologies offer new and impressive opportunities to support inquiry-based learning. With the integration of computer-related technologies for teaching, there has been an increase in teachers' use of different Internet-enabled applications in research classes. In this context, it can be stated that with the transfer of inquiry-based learning to web environments, teachers' 
Technological Pedagogical Content Knowledge will develop, and their self-efficacy will be positively affected.

\section{Argument-Based Learning}

Argumentation is the process of making claims about a subject using possessed data, finding justification and logical reasons for the claim (Demirel, 2017). Argumentation is often applied in science courses in the form of group discussions and defense of their own opinions based on appropriate observation, data and/or evidence (Güzel, Erduran, \& Ardaç, 2009). This process enables the production of scientific knowledge and the activation of cognitive and metacognitive mechanisms (Yaman, 2019).

During the argumentation process, students participate in the conversations, share their ideas and participate actively in the course (Kaya, Çetin, \& Erduran, 2014). In this process, students ask questions, form their claims and form their knowledge by supporting their claims with evidence (Günel, Kingir, \& Geban, 2012). Effective implementation of argumentation in classrooms is possible through a collaborative learning environment and mutual interaction between students (Tümay \& Köseoğlu, 2011). In this context, in the process of argumentation, students learn by sharing and discussing information in interaction in a collaborative work environment. Based on this, it can be stated that in parallel with the active participation of the participants in the process, self-efficacy will develop with argument-based learning.

Argumentation-based experiences provide an accurate understanding of concepts and interconceptual relations (Çinici, Özden, Akgün, Herdem, Deniz, \& Karabiber, 2014). During the argumentation process, students participate in scientific discussions and find reasons for their thoughts, produce evidence to prove their ideas and learn to respect opposing ideas (Demirel, 2016). This process requires the ability to make inferences from scientific texts, to recognize the standard types of science, their proper use, and to evaluate claims and evidence put forward in case of discussions (Simon, Erduran, \& Osborne, 2006). Having students experience this thought process helps them to grow up as students who are confident, can easily explain their thoughts, respect different opinions, have effective communication skills and experience the scientific process (Memis, 2017). In this context, it can be said that the argumentation process has many positive effects on students' selfconfidence, affective characteristics and learning.

It is suggested that the approaches and methods proposed or applied in the curriculum should be supported with technology. Similarly, the web-assisted processing of argumentation-based learning becomes important. In parallel with this situation, it is thought that the participants' self-confidence in technological pedagogical content knowledge will increase.

\section{STEM Education (Science, Technology, Engineering and Mathematics)}

STEM is an integrated teaching of real-life related subjects or problems by integrating them into science, technology, mathematics and engineering disciplines (Bakırcı \& Kutlu, 2018; Çakır \& Ozan, 2018; Özcan \& Koca, 2019). STEM is an approach that brings disciplines together, provides effective and high-quality learning, integrates knowledge into daily life and encompasses high-level thinking (Yıldırım \& Altun, 2015). STEM refers to teaching and learning in the fields of science, technology, engineering and mathematics and includes activities at all grade levels, from preschool to doctoral education (Gonzalez \& Kuenzi, 2012). In this context, STEM can be expressed as an interdisciplinary approach that can be applied at all levels of education.

Since STEM develops various literacy skills, it provides a bridge for individuals to prepare for a career (Wu, Marsono, \& Khasanah, 2019). Because STEM is an approach that puts forth products that can contribute to the national economy at the end of the process (Çevik \& Abdioğlu, 2018). Therefore, all STEM disciplines should be included in the STEM, and there should be more diversity in STEM professions for a workforce with technical and personal skills and for STEM literacy prepared to meet 
the challenges of the $21^{\text {st }}$ century (Bybee, 2010). In fact, the definition used as STEM education approach emphasizes the ability to raise productive, entrepreneurial, innovative individuals with $21^{\text {st }}$ century skills required by the present century (Barış \& Ecevit, 2019).

STEM education has many positive contributions to the students since it includes many disciplines and is oriented towards different skills. STEM is an interdisciplinary approach that enables the development of competitive ability and STEM literacy (Bircan, Köksal, \& Cımbız, 2019). In addition, STEM training contributes to the development of innovative skills (Şahin \& Kabasakal, 2018). In addition, STEM education provides students with skills such as high-level thinking skills, creativity skills, understanding that a problem can have more than one solution, courage, self-confidence, cooperation and effective communication skills (Deveci, 2018). With STEM education, students are taught a discipline while making connections with other disciplines and enabling them to learn other disciplines (Yıldırım \& Türk, 2018). As a result, the importance of an integrated, interdisciplinary STEM education that encourages students to learn about the natural world through experiences of exploration, questioning and problem solving is clear (Asghar, Ellington, Rice, Johnson, \& Prime, 2012). STEM education makes learning more meaningful both by addressing the issues associated with daily life and by establishing interdisciplinary relationships. In parallel with this situation, self-efficacy for learning develops positively. In addition, STEM education includes the fields of Science, Technology, Engineering, and Mathematics. In this context, in parallel with the learning of STEM education and the processing of the courses in this way, participants are expected to increase both their level of knowledge and self-confidence in these areas. Parallel to this situation, TPACK self-confidence of the participants is expected to improve positively.

\section{Method}

\section{Research Design}

In this study, pre-experimental research design was used. A pre-experimental design is a study in which there is no control group and the development of the subject or sample in terms of various variables (Çepni, 2018). As the effect of contemporary approaches education on prospective teachers' self-efficacy towards science teaching and TPACK self-confidence was investigated, it was considered appropriate to use the pre-experimental design because experimental design and the method taught were investigated through a single group.

\section{Study Group}

In this research, done in January 2018 , the study group was formed by selecting the appropriate sample in parallel with the selection of the experimental design. The study group consisted of prospective science teachers selected in the "Modern Approaches in Science Education Training for Science Teacher Candidates" project conducted within the scope of TUBITAK 2229 Scientific Activities Support Program. In this context, purposeful sampling method was used in the selection of the participating teachers in the study. In the selection of the teachers, a number of criteria were taken into consideration such as whether they have taken part in a study similar to this project, their academic grade point averages and their explanations about their intention to take part in the project. Within the scope of the project, applications were received for a certain period of time and 268 prospective teachers applied to the project. The academic grade point averages of the applicants were listed, and the selection was made from among the participants who had not been involved in a similar project before. In this process, it has been paid attention that the participants continue their education in different universities in different regions. As a result, prospective science teachers who were studying at 29 different universities in 7 different geographical regions of Turkey were selected. The study group consisted of 30 prospective science teachers attending $3^{\text {rd }}$ and $4^{\text {th }}$ grades. 


\section{Experiment Process}

The experimentation process consisted of 8 days and 8 hours of training each day and a total of 64 hours. These trainings were given by 11 faculty members who have proved their competence in the field through scientific studies published at national and international level. The applications were carried out in the meeting room in a hotel. On the first day, participants were informed about the training process, its purpose and its scope. Later, a drama event was organized by a faculty member specializing in drama in order to introduce and blend the teacher candidates. Then, a science curriculum was introduced by a faculty member who was an expert in science education. On the second day, the program presentation was focused on the recommended teaching methods in particular. After that, a theoretical presentation was made by an expert on inquiry-based learning to provide an overview of the inquiry and applications related to the inquiry process were made. On the third day, another expert lecturer on inquiry-based learning conducted theoretical and practical training on technology integration and evaluation methods in the interrogation process. In addition, examples of foreign applications related to the method were shown, allowing the prospective teachers to see more activity. Later, applications related to the method were carried out by an academician who specialized in Science Education. Here, it was aimed that the participants see a lot of applications related to the method.

On the fourth day, inquiry-based learning and STEM applications were carried out by two expert academicians with prospective teachers. Throughout the process, prospective teachers were enabled to use their inquiry skills effectively. The fifth day of argument-based learning method was carried out by two faculty members. First, information was given about the importance and processes of the argument, and then sample activities were carried out by creating a learning environment. Then the technology integration was emphasized, and applications were made using various tools. Finally, applications in different countries were presented to enable participants to see the situation in different countries. The sixth day was started with sample applications related to argument-based learning. In particular, web tools and applications were made in groups. Afterwards, small and large group discussions were carried out on how socio-scientific issues could be handled in argument-based learning method in science classes. Then, science and art activities were carried out in practice. On the seventh day, theoretical and practical training on the integration of STEM education into the classroom environment was given by an academic specializing in STEM. In this process, STEM activities were conducted in groups by students. After that, theoretical information about robotic applications was given by a faculty member and Lego applications were carried out in groups. In this process, it was deemed important to present different examples of STEM training. On the last day, STEM activities continued, and the process was completed.

The application process focused on the vision of science curriculum, unit structures and achievements, inquiry-based learning in science education, argumentation-based learning, STEM education, and the use of technology in science course. The trainings were completed in the form of sharing theoretical knowledge about the subject with prospective science teachers as well as providing on-site and on-time effective practical training on the subject taught.

\section{Data Collection Tools}

As a data collection tool, "Science Teaching Efficacy Belief Instrument" and "Technological Pedagogical Content Knowledge Confidence Survey" were used as preliminary test and final test. The science teaching efficacy belief instrument was developed in 1990 by Riggs and Enochs and adapted to Turkish by Özkan, Tekkaya and Çakıroğlu (2002). This 25-item instrument uses a 5-point Likert scale. The scale consists of two factors: Self-efficacy belief in science teaching ( 13 items) and expectation of outcome in science teaching (10 items). The reliability value for the belief in self-efficacy belief in science by Özkan and others was found to be .79 and the reliability value for the expectation of results in science education was .86. In the scope of the study, the reliability value of Cronbach Alpha was 
found to be .82 . In addition, in order to ensure the content and face validity of the scale, it was presented to expert opinion and it was concluded that the scale items were suitable for the intended purpose.

Technological Pedagogical Content Knowledge Confidence Survey, which is another data collection tool used in the study, was developed by Graham, Burgoyne, Cantrell, Smith, and Harris (2009) and Cronbach's alpha reliability value was found to be .95. The scale was adapted to Turkish by Timur and Taşar (2011). The scale is a 5-point Likert and consists of 31 items. The scale consisted of four subdimensions as The Content Knowledge (TPCK), Technological Pedagogical Knowledge (TPK), Technological Content Knowledge (TCK) and Technological Knowledge (TK). Reliability analysis of the instrument revealed that the Cronbach-Alpha coefficient was (.92) for the whole of the instrument. In addition, the CFA analysis of the scale yielded $\chi 2 / d f=2.86(p=.000), N F I=.87$ and RMSEA $=.069$. In this study, Cronbach Alpha reliability value was calculated as .89. The scale used in this process was examined by two experts for content and face validity. As a result of the investigations, it was concluded that the scale measured the desired characteristics.

\section{Data Analysis}

The data obtained from the study were analyzed with the help of SPSS package software. In this process, positive items loaded to the software remained the same, while negative items were reversed and included in the system. Then, kurtosis and skewness values were examined to determine whether the data showed normal distribution. The skewness value was calculated as .437 and the kurtosis value was .806 for "Science Teaching Efficacy Belief Instrument". Technological Pedagogical Content Knowledge Confidence Survey had a skewness value of .336 and a kurtosis value of .924. In this context, since all values are between -1 and 1 , it can be said that the data is normally distributed. In parallel with this situation, it was found appropriate to carry out the dependent groups t-test. In order to increase the reliability and validity of the study, it can be said that the group is heterogeneously distributed and prospective teachers in different universities are preferred and the conditions of application are controlled.

\section{Results}

In this part of the study, findings on the differences in self-efficacy of prospective teachers of contemporary approaches education towards science teaching and findings on differences in technological pedagogical content knowledge (TPACK) self-confidence of contemporary approaches education are given.

\section{Findings about the Differences in Prospective Teachers' Self-Efficacy towards Science Teaching of Contemporary Approaches Education}

In this study, dependent groups t-test was used to determine the differences in self-efficacy of prospective teachers' teaching towards science teaching. Pre-test and post-test scores t-test results on prospective teachers' self-efficacy towards science teaching are given in Table 1.

Table 1.

Results of t-test for Pre-test and Post-test Scores of Prospective Teachers' Self-Efficacy towards Science Teaching

\begin{tabular}{lcccccc}
\hline Test & $\mathbf{N}$ & $\overline{\mathbf{X}}$ & SS & SD & t & $\mathbf{p}$ \\
\hline Pre-test & 30 & 73.06 & 8.21 & \multirow{2}{*}{58} & -0.70 & .944 \\
Post-test & 30 & 73.20 & 6.38 & & & \\
\hline
\end{tabular}

As shown in Table 1, there was no significant difference in the pre-test-final test scores for selfefficacy in science teaching of prospective teachers $(t(58)=-0.70, p>.05)$. In this context, it can be said that contemporary approaches education does not cause a significant increase in prospective teachers' self-efficacy towards science teaching. The mean pre-test scores of the prospective teachers were found to be 73.06 and the post-test scores were 73.20. At this point, it can be stated that there was no significant increase in the mean scores of the participants. In addition, considering that the lowest 
score is 23 and the highest score is 115 , it can be said that prospective teachers' self-efficacy towards science teaching is moderate or good. Table 2 shows the results of the t-test for the pre-test and posttest scores for the sub-dimensions of the prospective teachers' self-efficacy scale for science teaching.

Table 2.

t-test Results of Pre-Test and Post-Test Scores on Sub-dimensions of Prospective Teachers' Self-Efficacy Scale for Science Teaching

\begin{tabular}{llllllll}
\hline Sub-Dimension & Test & $\mathbf{N}$ & $\overline{\mathbf{X}}$ & SS & SD & t & p \\
\hline Personal Teaching Efficacy on & Pre-test & 30 & 37.20 & 5.79 & \multirow{2}{*}{58} & \multirow{2}{*}{.953} & \multirow{2}{*}{.345} \\
Science Teaching & Post-test & 30 & 36.07 & 2.97 & & & \multirow{2}{*}{292} \\
\hline Outcome Expectancy in Science & Pre-test & 30 & 35.87 & 3.97 & \multirow{2}{*}{58} & \multirow{2}{*}{-1.063} & \multirow{2}{*}{. } \\
Teaching & Post-test & 30 & 37.13 & 5.17 & & & \\
\hline
\end{tabular}

When Table 2 was examined, it was found that there was no significant difference between pretest and post-test scores of prospective teachers' self-efficacy belief in science teaching $(t(58)=.958$, $p>.05)$ and expectation of results in science teaching $(t(58)=-1.063, p>.05)$. It can be said that contemporary approaches education does not cause a significant increase in the sub-dimensions of prospective teachers' self-efficacy towards science teaching.

Findings on the Effect of Contemporary Approaches Education on Science Teachers' Technological Pedagogical Content Knowledge (TPACK) Self-Confidence

In the study, dependent groups t-test was used to determine the differences in TPACK selfconfidence of prospective teachers of contemporary approaches to education. Pre-test and post-test t-test results related to TPACK self-confidence of prospective science teachers are given in Table 3 .

Table 3.

t-test Results of Pre-test and Post-test related to TPACK Self-Confidence of Prospective Teachers'

\begin{tabular}{lcccccc}
\hline Test & $\mathbf{N}$ & $\overline{\mathbf{X}}$ & $\mathbf{S S}$ & $\mathbf{S D}$ & $\mathbf{t}$ & $\mathbf{p}$ \\
\hline Pre-test & 30 & 130.77 & 12.97 & \multirow{2}{*}{58} & \multirow{2}{*}{-3.35} & \multirow{2}{*}{001} \\
Post-test & 30 & 141.90 & 12.80 & & \\
\hline
\end{tabular}

As shown in Table 3, there was a significant difference in TPACK self-confidence pre-test and posttest scores of prospective science teachers $(t(58)=-3.35, p<.05)$. It can be said that contemporary approaches education has caused a significant increase in the prospective teachers' TPACK selfconfidence in favor of post-test. The mean pre-test scores of the prospective teachers were 130.77, whereas the post-test scores were 141.90. At this point, it can be stated that there is a significant increase in the TPACK self-confidence of the prospective teachers, and this is parallel to the education provided. In addition, the lowest score that can be obtained from the TPACK self-confidence scale is 31 , and the highest score is 155 , and it can be said that prospective teachers have a high selfconfidence of TPACK, since the post-test average is 142. The t-test results of the pre-test and post-test scores regarding the sub-dimensions of the TPACK self-confidence scale of the prospective teachers are given in Table 4.

Table 4.

t-test Results of Pre-test and Post-test Scores of The Prospective Teachers' TPACK Self-Confidence Scale according to Sub-Dimensions

\begin{tabular}{|c|c|c|c|c|c|c|c|}
\hline Sub-dimension & Test & $\mathbf{N}$ & $\overline{\mathbf{x}}$ & SS & SD & $\mathbf{t}$ & $\mathbf{p}$ \\
\hline \multirow{2}{*}{ TPACK } & Pre-test & 30 & 34.60 & 3.39 & \multirow{2}{*}{58} & \multirow{2}{*}{-3.502} & \multirow{2}{*}{.001} \\
\hline & Post-test & 30 & 37.50 & 3.00 & & & \\
\hline \multirow{2}{*}{ TPK } & Pre-test & 30 & 29.73 & 3.55 & \multirow{2}{*}{58} & \multirow{2}{*}{-2.593} & \multirow{2}{*}{.012} \\
\hline & Post-test & 30 & 32.13 & 3.62 & & & \\
\hline \multirow{2}{*}{ TCK } & Pre-test & 30 & 21.57 & 2.46 & \multirow{2}{*}{58} & \multirow{2}{*}{-2.524} & \multirow{2}{*}{.014} \\
\hline & Post-test & 30 & 23.07 & 2.13 & & & \\
\hline \multirow{2}{*}{ TK } & Pre-test & 30 & 44.87 & 5.84 & \multirow{2}{*}{58} & \multirow{2}{*}{-2.852} & \multirow{2}{*}{.006} \\
\hline & Post-test & 30 & 49.20 & 5.93 & & & \\
\hline
\end{tabular}


When Table 4 was examined, a significant difference was found in favor of post-test between the pre-test and post-test scores of TPACK $(t(58)=-3.502 p<.05)$, TPK $(t(58)=-2.593, p<.05)$, TCK $(t(58)=-$ $2.524, p<.05)$ and TK $(t(58)=-2.852, p<.05)$ which are sub-dimensions of the scale. At this point, it can be stated that the contemporary approaches education leads to a significant increase in each subdimension of the TPACK self-confidence scale of prospective teachers.

\section{Discussion, Conclusion and Implications}

According to the findings of the present study, there was no significant difference between pre-test and post-test scores of prospective teachers' self-efficacy towards science teaching. Similarly, there was no significant increase in the self-efficacy beliefs and the outcome expectations of prospective science teachers in science teaching. At this point, it can be said that contemporary approaches education does not cause a significant difference in the development of self-efficacy of prospective science teachers towards science teaching. However, in the literature, it was concluded that inquirybased learning positively improved the self-efficacy of science teacher candidates towards academic or science teaching (Kayacan \& Selvi, 2017; Şensoy, \& Aydoğdu, 2008). In addition, it was determined that the argumentation-based inquiry method had a significant effect on science teacher candidates' self-efficacy belief sub-dimensions (self-efficacy belief in science teaching and outcome expectations in science teaching) (Eymur \& Çetin, 2017). It was concluded that constructivist approach (Kutluca \& Aydın, 2016), problem-based learning approach (Yaman \& Yalçın, 2005), and the use of animation and simulation for the experiment (Yener et al., 2012) improved participants' self-efficacy beliefs for science/physics teaching. However, in parallel with the present study, there are studies in the literature that different contemporary learning approaches have no effect on self-efficacy. In the studies, it was determined that project-based teaching practices had no effect on prospective science teachers' selfefficacy towards physics (Çıbık, Ince, \& Kayacan, 2016) and problem-based learning on the participants' self-efficacy belief levels (Gürlen, 2011; Yurdatapan, 2013). This result, obtained in the current study, was unexpected. Because it was thought that the trainings received, especially the trainings, which involve practice and which the participants themselves actively participate in the process, will positively affect their self-sufficiency. In these applications, it is expected that self-efficacy will improve when it is thought that prospective teachers are active and do the activities themselves. The literature also supports this situation. Their self-proficiency in science education is increasing as the teaching model moves from teacher-centered to student-centered teaching model (Feyzioğlu, Feyzioğlu, \& Küçükçıngı, 2014). On the other hand, the reason for the lack of improvement in our study is thought to be due to the intensified short-term education. The training is short in the context of the number of days, although it is a training that appears to be long when we look at it as training hours. In this context, it is thought that long-term programs, rather than intensification, may be more effective in future studies.

In the present study, the average score of prospective science teachers on the self-efficacy scale towards science teaching was 73 . At this point, it can be said that the prospective teachers' self-efficacy towards science teaching is moderate and good. In the studies conducted in the literature, it was found that the prospective biology teachers 'self-efficacy beliefs in biology teaching (Gerçek, Yılmaz, Köseoğlu, \& Soran, 2006) and the prospective science teachers' self-efficacy towards science teaching were high (Denizoğlu, 2008). In the study of Berkant and Ekici (2007), it was determined that prospective teachers' self-efficacy beliefs in science teaching were found to be moderate. Şenler (2017), on the other hand, concluded that prospective teachers' self-efficacy belief scores towards science teaching were well above the average. The most important factor in whether prospective teachers' self-efficacy levels are moderate or high depends on how high their grade levels are. Similarly, Yaman et al. (2004) reported that the higher the grade level, the higher the self-efficacy belief level towards science teaching. This is thought to be due to the positive development of their beliefs in science education in parallel with the fact that the prospective teachers have seen many courses in science education at the University. Another factor in the levels of self-efficacy of teacher candidates 
towards science teaching is thought to be due to their high academic achievement. As Akbaş and Çelikkaleli (2006) stated that as academic achievement increases, self-efficacy belief in science teaching increases as well. In parallel with this situation, it is considered that the self-efficacy of the participant group is high in parallel with their high academic success levels.

In the present study, it was understood that contemporary approaches education improved TPACK self-confidence of prospective science teachers positively. Similarly, there was a significant difference in all sub-dimensions in favor of the post-test. At this point, it can be said that the contemporary approaches education has caused a significant difference in the development of TPACK self-confidence of the prospective teachers. It can be said that similar results have been reached in studies conducted with different teaching methods in the literature. Kılıç (2015) stated that TPACK-based blended learning environment positively improves the prospective science teachers' TPACK levels on basic astronomy subjects. Tatlı, Akbulut and Altınışık (2016) concluded that the use of Web 2.0 tools for educational purposes caused a significant increase in TPACK self-confidence levels of prospective teachers. In their study, Özkara, Konokman, and Yanpar-Yelken (2018) concluded that access to and interest in technology is a variable that differentiates teachers' TPACK self-confidence levels. As can be understood, one of the most important factors in the development of TPACK self-confidence of prospective teachers is the effective use of both technology and teaching methods in the process. In these contemporary approach education practices, both methods are studied in depth in terms of knowledge and application and technology integration is emphasized in detail. In parallel with this situation, it is a desirable and expected result to increase the TPACK self-confidence of prospective teachers. In this context, it is thought that more emphasis should be placed on the integration of technology during university education. Similarly, Korucu, Usta, and Atun (2017) state that it is important to train teachers according to TPACK framework in order to minimize the inconveniences of integrating technology to the teaching process.

In the current study, the average score of prospective science teachers on the TPACK selfconfidence scale was 142 . In this context, it can be said that prospective teachers' TPACK selfconfidence is high. Similarly, TPACK self-confidence levels of science teachers were found to be high in the literature (Bağdiken \& Akgündüz, 2018; Cesur Özkara et al., 2018; Meriç, 2014). Although TPACK self-confidence is found to be high in all studies, it can be said that there are deficiencies and problems in applications. It can be said that there is a need for studies focusing on this subject and investigating the process in detail in the literature with quantitative and qualitative data.

According to the results of the study, it was understood that the contemporary approaches applied did not cause a significant difference in self-efficacy of prospective science teachers' self-efficacy towards science teaching, but it caused a significant difference in technological pedagogical content knowledge self-confidence. In the context of both variables, it is thought that both the practical orientation of the education and the fact that it contains technology support improved the selfconfidence and self-efficacy of the participants in science teaching. In parallel with this situation, it can be suggested that similar training would be important for both prospective teachers and teachers. However, despite the implementation of a busy schedule as the course hours, there have been some setbacks due to the fact that it covers a short period of time. In this context, it can be stated that it would be more appropriate to provide similar trainings by spreading them over several weeks and academic studies would be conducted from these trainings would be important for the literature. In addition, it can be suggested that the effectiveness of education can be done by using qualitative data collection tools in addition to quantitative data collection tools for similar variables.

\section{Acknowledgement}

This study is part of "Modern Approaches in Science Education Training for Science Teacher Candidates", supported by TUBITAK 2229- Scientific Activities Support Program. The abstract of this 
Ümmühan Ormancı, Sevinç Kaçar, Erkan Özcan, A. Günay Balım - Uluslararası Eğitim Programlar ve Öğretim Çalışmaları Dergisi, 10(1), 2020, 1-28 research was presented as an oral presentation at the IX. International Congress of Research in Education. 


\section{TÜRKÇE SÜRÜM}

\section{Giriş}

Fen öğretimi, bireylerin yaşamlarında ve doğada gerçekleşen olgu ve olayları fark etmeleri ve bu olay/olguları bilimsel açıdan değerlendirebilmeleri için önemli bir disiplindir. Fen bilimleri dersinin temel amacı, öğrencilerin kendilerini ve çevrelerini tanıyan, karşılaştıkları problemlere çözüm bulabilen, eleştirel, yaratıcı vb. düşünebilen bireyler olmalarını sağlamaktır. Bu duruma paralel olarak Milli Eğitim Bakanlığı [MEB] (2018) bilgiyi üretip kullanabilen, karşılaştığı problemleri çözebilen, eleştirel düşme- girişimcilik- iletişim becerilerine sahip vb. niteliklerdeki bireylerin yetişmesine hizmet edecek öğretim programlarının hazırlandığını belirtmiştir. Bu amaç doğrultusunda fen programlarında fen okuryazarı bireyler yetiştirmek hedeflenmektedir. Ülkemizde ve diğer birçok ülkede (Amerika, Ingiltere, Singapur vb.) fen öğretim programının vizyonu fen okuryazarı bireyler yetiştirmek olarak belirlenmiştir. Fen okuryazarı bireylerden; fen bilimlerine ilişkin temel bilgilere (biyoloji, fizik, kimya, yer, çevre bilimleri, fen ve mühendislik uygulamaları) ve doğal çevrenin keşfedilmesine yönelik bilimsel süreç becerilerine sahip olmaları beklenmektedir (MEB, 2013; 2018). Bu bağlamda üst düzey düşünme becerilerine sahip ve bilgiyi günlük yaşamlarında kullanabilen bireyler olmak fen programlarının temel vizyonu olan fen okuryazarlığı ile birebir ilişkilidir.

Ülkeler fen öğretim programları geliştirmekte ya da var olan programlarında çağın gereksinimleri doğrultusunda değişikliklere gitmektedirler. Yirminci yüzyılın ikinci yarısında, bilginin büyümesi ve gelişimi konusundaki anlayışlarda değişiklikler yaşanmış (Duschl \& Osborne, 2002) ve bu durum öğretim programlarına yansımıştır. Bilgi çağı içinde olduğumuz düşünüldüğünde; öğrencilere, mevcut bilgileri aktarmaktan ziyade bilgiye ulaşma becerilerinin kazandırması sağlanmalıdır (Duran, 2016). Bu duruma paralel olarak ülkeler öğretim programlarını değiştirerek, davranışçılıktan yapılandırmacılığa doğru kayan öğretim anlayışını benimsemeye başlamışlardır (Güneş, Sağdıç, \& Şimşek, 2018). Buna paralel olarak ülkemiz fen bilimleri öğretim programı araştırma-sorgulamaya dayalı öğrenme, argümantasyona dayalı öğrenme, STEM eğitimi gibi birçok yeni yönteme uygun olarak hazırlanmıştır.

Araştırma-sorgulamaya dayalı öğrenme yaklaşımı, fen okuryazarı bireyler yetiştirmeyi amaçlamaktadır (Duran, 2015). Ayrıca Sever ve Güven'in (2012) belirttiği gibi araştırma-sorgulamaya dayalı öğrenme; bağımsız ve yaşam boyu öğrenen bireyler olma, grafik okuma, problem çözme, yaratıcı ve eleştirel düşünme gibi becerileri kazandırmayı hedeflediğinden, fen okuryazarı bireylerden beklenen özelliklerle büyük ölçüde örtüşmektedir. Bununla birlikte okuryazar bireyler yetişmesi için gerekli beceriler noktasında öne çıkan yaklaşımlardan bir diğeri ise argümantasyon tabanlı bilim öğrenmedir (Duran, Doruk, \& Kaplan, 2017). Son olarak ise uluslararası alanyazında 90'lı yıllarda ve ülkemizde son dört yıldır çalışıımaya başlanan STEM (Herdem \& Ünal, 2018), fen programlarında etkin bir şekilde ifade edilmeye başlamıştır. Türk Sanayicileri ve iş İnsanları Derneği (TUSiAD) (2017); Türkiye'nin genç nüfusunun potansiyelini ortaya çıkarabilmek için STEM altyapısı kazandırılması, bunun için de yaratıcı, disiplinler arası düşünebilen, bilişim ve iletişim becerilerine sahip bir işgücü yaratılması gerektiğini ifade etmiştir. Anlaşılacağı üzere STEM eğitimine ve becerilerine ihtiyaç olması küresel ekonominin ve işgücü gereksinimlerinin değişmesinden kaynaklanmaktadır (Kennedy \& Odell, 2014). Bu bağlamda gerek fen bilimlerinin doğası gereği, gerek ülkelerin gelişmesi için gerekli becerilere sahip bireylerin yetişmesinde STEM eğitimi başta olmak üzere çağdaş yaklaşımların önemi ortaya çıkmaktadır.

Fen okuryazarı bireylerin yetişebilmesi için öğretmen ve öğretmen adaylarına büyük görevler düşmektedir. Öğretmenlerin branşlarında etkili ve başarılı olabilmeleri, hizmet öncesi eğitim sırasında iyi yetişmeleri ile paralellik göstermektedir (Azar, 2011). Öğretmenlerin rollerini başarılı bir şekilde sürdürebilmeleri için ilk olarak alanlarında iyi yetişmiş bireyler olmaları beklenmektedir (Kavas \& Bugay, 2009). Bu açıdan öğrencilerin gerekli becerilerle yetiştirilebilmesi için öğretmenlerin bunları uygulayabilecek çağdaş yaklaşımları bilmeleri ve etkin bir şekilde uygulamaları gerekmektedir. Alanyazın incelendiğinde araştırma-sorgulamaya dayalı öğrenme, öğretmenlerin sahip oldukları geleneksel inanış ve uygulamalardan dolayı beklenen düzeyde uygulanamamaktadır (Duran \& Dökme, 
2018). Benzer durum argümantasyon ve STEM eğitimi için de geçerlidir. Bakırcı ve Kutlu (2018) yeterli sayıda ve nitelikte STEM eğitimi almış öğretmenlere ihtiyaç olduğunu belirtmektedir. Bu bağlamda öğretmen ve öğretmen adaylarının çağdaş yaklaşımları uygulamaya yönelik bakış açılarını değiştirecek, uygulama için gerekli kaynakları sağlayacak, öğretmenlerin bu tarz çalışmalara katılımlarını teşvik edecek çalışmaların yapılması gerekmektedir (Yıldırır \& Nakiboğlu, 2014).

Öğretmenlerin lisans eğitimi sırasında onlara verilen derslerin ve kursların önemi ortaya çıkmaktadır. Bu noktada ilköğretim fen bilimleri programlarında çağdaş yaklaşımların (STEM, araştırma-sorgulamaya dayalı öğrenme gibi) temel alınmasına rağmen, üniversitelerde eğitim fakültelerinde bu yöntemlerin etkin olarak işlenmediği veya üniversiteden üniversiteye farklılıklar yaşandığı ifade edilebilir. Ancak 2018'de uygulanmaya başlanan "Fen Bilgisi Öğretmenliği Lisans Programı (2018)" ile birlikte bu durumun daha olumlu yöne gittiği ve fen öğretimine yönelik ders sayısının arttığı söylenebilir. Program kapsamında "Fen Öğrenme ve Öğretim Yaklaşımları", "Fen Öğretim Programları", "Fen Öğretimi 1", "Fen Öğretimi 2" gibi fen öğretimine yönelik dersler yer almaktadır. Bu derslerin içeriğine bakıldığında birçok konu yer almakta olup fen öğretiminde kullanılan yaklaşım/ yöntemlere yer verilmesi gerektiği ifade edilmiştir. Sadece "Fen Öğretimi 2" dersi kapsamında, ilköğretim programında yer alan ve bu çalışma kapsamında ifade edilen yaklaşım/ yöntemlere yer verilmiştir. Ders kapsamında bu yöntemler dışında, öğrencilere birçok yaklaşım/ yöntem ve beceri de kazandırılması hedeflenmektedir. Bu bağlamda ders kapsamında bu yaklaşımlara ortalama birer haftalık ders saati ayrılabileceği ifade edilebilir. Ancak öğretmen adaylarının ileride fen bilimleri derslerini bu yaklaşımlara paralel olarak işlemeleri istendiği düşünüldüğünde, bu zamanın yeterli olmayacağı açıktır. Anlaşılacağı üzere fen bilgisi öğretmenliği programı kapsamında, ilköğretim programında yer alan yöntem ve tekniklerin faklı ders içeriklerinde yer aldığı ancak sadece bu yöntemlere odaklanan zorunlu veya seçmeli dersin olmadığı ifade edilebilir. Bu noktada fen bilimleri öğretim programında yer alan yaklaşımlara yönelik oluşturulacak bir dersin veya eğitimlerin önemi ortaya çıkmaktadır. Çünkü çağdaş yaklaşımların tanıtılacağı ve fen derslerinde nasıl uygulanabileceğinin gösterileceği eğitimlerin öğretmen adayları için büyük önem taşıdığı düşünülmektedir. Öğretmen adaylarına, öğretmenlik mesleğine başlamadan önce bu yaklaşım/yöntemlere ilişkin bilgi verilmesi, farkındalık oluşturulması ve uygulayıcıları haline getirilmesinin önemli olduğu düşünülmektedir.

Bu çalışmada, fen bilgisi öğretmen adaylarına çağdaş yaklaşımlar eğitimi verilmiş ve eğitimin öğretmen adayları üzerindeki etkililiği araştııılmıştır. Bu amaçla seçilen değişkenlerden biri fen öğretimine yönelik öz yeterliktir. Öğretmen öz yeterlik inancı, öğretme görevini başarılı bir şekilde uygulayabilmek için gerekli davranışları göstermeye yönelik inanışlardır (Yener, Aydın, \& Köklü, 2012). Fen eğitiminde öz yeterlik, fen öğretmen ve öğretmen adaylarının feni öğretmeye ve sınıf içi etkinlikler hakkındaki inançlar ile ilişkilidir (Yaman, Cansüngü Koray, \& Altunçekiç, 2004). Öğretmenlerin/ öğretmen adaylarının STEM, argümantasyona dayalı öğrenme, araştırma-sorgulamaya dayalı öğrenme gibi yapılandırmacı felsefeye dayanan yaklaşımları uygulayabilmeleri için bu yaklaşımları kullanarak fen bilimlerini etkili bir şekilde işleyeceklerine yönelik inançlarının ve becerilerinin tam olması beklenmektedir. Bu bağlamda öğretmen adaylarının bu yaklaşımlara yönelik bilgi ve tecrübeleri arttıkça, fen bilimlerini daha iyi öğretebilecekleri ve fen öğretimine yönelik öz yeterliklerinin yüksek olacağı düşünülmektedir. Zaten fen bilimlerinin etkili bir şekilde öğretilebilmesi için öğretmenlerin fen öğretimine yönelik öz yeterliklerinin yüksek olması beklenmektedir. Yurdatapan'ın (2013) belirttiği gibi katıımcıların aktif olduğu öğretim yaklaşımları kullanıldığında, kendine güvenen ve yeterli hisseden bireyler yetiştirilebilmektedir. Bu duruma paralel olarak bu çalışmada çağdaş yaklaşımlar eğitiminin öğretmen adaylarının fen öğretimine yönelik öz yeterliklerine etkisi incelenmiştir.

Çalışma kapsamında seçilen diğer bir değişken ise teknolojik pedagojik alan bilgileri (TPAB) özgüvenidir. Eğitim kapsamında yer alan tüm yaklaşımlar TPAB ile birebir ilişkilidir. Bu noktada bu yaklaşımlara yönelik yapılan eğitimlerin öğretmen adaylarının TBAP ilişkin özgüvenlerinde olumlu sonuçlar doğuracağı düşünülmektedir. Ayrıca TPAB geleceğin öğretmenleri için önemli bilgiler arasında 
(Korucu, Usta, \& Atun, 2017) olup tüm öğretmenlerin meslekleri sürecinde TPAB'larından yararlanmaları gerektiği düşünülmektedir (Balçın \& Ergün, 2019). Bu duruma paralel olarak bu çalışmada öğretmen adaylarının TPAB öz güvenlerinin seçilmesi uygun görülmüştür. Anlaşılacağı üzere hem öğretmen mesleği süreci hem de çağdaş yaklaşımlar ile yakından ilişkili olan iki değiş̧ken seçilmiştir. Bu bağlamda bu çalışmada çağdaş yaklaşımlar eğitiminin öğretmen adaylarının fen öğretimine yönelik öz yeterliklerine ve teknolojik pedagojik alan bilgileri (TPAB) özgüvenlerine etkisinin araştırılması amaçlanmıştır. Bu duruma paralel olarak çalışmanın araştırma soruları şu şekildedir:

1. Çağdaş yaklaşımlar konusunda eğitim alan fen bilimleri öğretmen adaylarının fen öğretimine yönelik öz yeterlikler ön-test ve son-test puanları arasında anlamlı bir fark var mıdır?

2. Çağdaş yaklaşımlar konusunda eğitim alan fen bilimleri öğretmen adaylarının teknolojik pedagojik alan bilgisine (TPAB) yönelik özgüven ön-test ve son-test puanları arasında anlamlı bir fark var mıdır?

\section{Kuramsal Çerçeve}

\section{Araştırma-Sorgulamaya Dayalı Öğrenme}

Araştırma-sorgulamaya dayalı öğrenme; yapılandırmacı bir yaklaşım olmakla birlikte, öğrenenlerin sözlü etkileşimden ve deneyimlerden yararlanarak kavramları yapılandırmalarını sağlayan bir yöntemdir (Schmid, 2015). Araştırma-sorgulamaya dayalı öğrenme, bilim insanlarının çalışmalarına paralel bir şekilde ilgi çeken bilimsel soruşturmalara benzetilebilir (Capps \& Crawford, 2013). Süreç boyunca öğrenciler bilim insanı gibi çalışıp, gerekli olan araştırmaları yaparak bilgiyi yapılandırmaya çalışmaktadırlar. Tan ve Tan'ın (2014) belirttiği üzere araştırma-sorgulamaya dayalı öğrenme öğrencileri kendi öğrenmelerine sahip çıkan aktif öğrenenler olarak geliştirmeyi amaçlamaktadır. Araştırma-sorgulamaya dayalı öğrenmede bireylerin aktif olarak sürece ortak olmalarına paralel olarak kendi öğrenmelerinden kendileri sorumlu olmaktadır. Bu duruma paralel olarak araştırmasorgulamaya dayalı öğrenme ile birlikte öğrenmeye yönelik öz yeterlik olumlu yönde etkilenmektedir.

Araştırma-sorgulamaya dayalı öğrenme sürecinde öğrenciler; genellikle karmaşık ve doğrusal olmayan süreçleri yansıtan günlük yaşam problemleri ile çalışmaktadırlar (Şaşmaz-Ören, Ormancı, Babacan, Çiçek, \& Koparan, 2010; Werner, 2007). Ayrıca bu süreçte; bilim insanı çalışma sürecine benzer etkinliklere katılma ve uygulamalarına imkân verdiği için, bilimsel kavramların anlaşılmasına yardımcı olmaktadır (Apedoe, Walker, \& Reeves, 2006). Anlaşılacağı üzere araştırma-sorgulama sürecinde öğrenciler aktif rol aldıklarından öğrenmeleri de olumlu yönde gelişmektedir. Bununla birlikte araştırma-sorgulamaya dayalı öğrenme, öğrencilerde merak ve ilgi uyandırmaktadır (SpronkenSmith, Bullard, Ray, Roberts, \& Keiffer, 2008). Bu da öğrencilerin hem derse olan ilgilerini arttırmakta hem de sürece daha etkin olarak katılmalarını sağlamaktadır. Sonuç olarak Duran ve Dökme'nin (2018) belirttiği gibi araştırmaya dayalı öğrenme yaklaşımı uygulandığında öğrenciler, süreç boyunca aktif olmakta, bilimsel süreç becerilerini kullanan, tartışmalar ve etkinlikler yaparak düşünme becerilerini gelişen bireyler olarak yetişmektedir.

Araştırma-sorgulama sürecinde öğrenciler; yeni bilgiler üretmek için bilim insanı gibi düşünme süreçleriyle ve çeşitli etkinliklerle meşgul olmaktadırlar (Abdi, 2014). Öğrenciler bağımsız-özgür öğrenenler olmak için güçlendirilmekte (Gibson, 1998), pasif dinleyici rolünden çıkıp aktif katılımcı olarak davranmaktadırlar (Tatar, 2006). Öğretmen ise bu süreçte rehber konumda etkin olarak yer almaktadır. Bu duruma paralel olarak araştırma-sorgulamaya dayalı öğrenmede bilimsel öğrenme, bilimsel gerçek ve bilgilerin ezberlenmesinden daha ziyade bilimsel kavram ve yöntemlerin uygulanması ve anlaşılması ön planda olmaktadır (Bell, Urhahne, Schanze, \& Ploetzner, 2010).

Teknolojideki gelişmelere paralel olarak, teknolojinin ders içeriklerine ve sürecine entegre edilmesi ön plana çıkmaya başlamıştır. Bu duruma paralel olarak Edelson, Gordin ve Pea'nın (1999) belirttiği üzere bilgisayar ve ağ teknolojileri, araştırma-sorgulamaya dayalı öğrenmeyi desteklemek için yeni ve etkileyici fırsatlar sunmaktadır. Öğretim için bilgisayarla ilgili teknolojilerin entegrasyonuyla, araştırma sınıflarında öğretmenlerin internet içeren farklı uygulamaları kullanmalarında artma meydana 
gelmiştir. Bu bağlamda araştırma-sorgulamaya dayalı öğrenmenin web ortamlarına aktarılması ile birlikte öğretmenlerin teknolojik pedagojik alan bilgilerinin gelişeceği ve buna yönelik öz yeterliklerinin olumlu etkileneceği ifade edilebilir.

\section{Argümantasyona Dayalı Öğrenme}

Argümantasyon, sahip olunan verileri kullanarak bir konu ile ilgili iddia üretme, üretilen iddiaya gerekçe ve mantıklı nedenler bulma işlemidir (Demirel, 2017). Argümantasyon fen derslerinde, öğrencilerin çoğunlukla grup şeklinde, oluşturdukları iddiaları uygun gözlem, veri ve/veya kanıtlara dayandırarak tartışmaları ve kendi görüşlerini savunmaları şeklinde uygulanmaktadır (Güzel, Erduran, \& Ardaç, 2009). Bu süreç, bilimsel bilginin üretilmesini, bilişsel ve üst bilişsel mekanizmaların harekete geçmesini sağlamaktadır (Yaman, 2019).

Argümantasyon sürecinde, öğrenciler konuşmalara katılmakta, fikirlerini paylaşmakta ve derse aktif katııım sağlamaktadırlar (Kaya, Çetin, \& Erduran, 2014). Bu süreçte öğrenciler, sorular sormakta, iddialarını oluşturmakta ve iddialarını delillerle destekleyerek bilgilerini oluşturmaktadırlar (Günel, Kıngır \& Geban, 2012). Argümantasyonun sınıflarda etkili bir şekilde uygulanması, işbirlikçi bir öğrenme ortamı ve öğrencilerin kendileri arasındaki karşılıklı etkileşimleri mümkün olabilmektedir (Tümay \& Köseoğlu, 2011). Bu bağlamda argümantasyon sürecinde öğrenciler işbirlikli çalışma ortamında etkileşim içinde bilgileri paylaşarak ve tartışarak öğrenmektedirler. Bu bağlamda argümantasyona dayalı öğrenme ile birlikte katılımcıların süreç içerisinde etkin olarak yer almalarına paralel olarak öz yeterliklerinin gelişeceği ifade edilebilir.

Argümantasyona dayalı deneyimler, kavramların ve kavramlar arası ilişkilerin doğru anlaşımasını sağlamaktadır (Çinici, Özden, Akgün, Herdem, Deniz, \& Karabiber, 2014). Argümantasyon sürecinde öğrenciler bilimsel tartışmalara katılarak düşüncelerine gerekçeler bulmakta, fikirlerini kanıtlamak için deliller ortaya çıkarmakta ve karşıt düşüncelere saygı duymayı öğrenmektedirler (Demirel, 2016). Bu süreç bilim metinlerinden anlam çıkarma, bilimin standart türlerini, uygun kullanımlarını ve tartışma durumunda ileri sürülen iddiaları ve kanıtları değerlendirme yeteneğini tanıma becerisini gerektirmektedir (Simon, Erduran, \& Osborne, 2006). Bu düşünce sürecini öğrencilerin yaşaması onların kendine güvenen, düşüncelerini rahatlıkla açıklayan, başkalarının düşüncelerine saygı duyan, etkili iletişim becerisine sahip ve bilimsel süreci yaşayan öğrenciler olarak yetişmelerine yardımcı olmaktadır (Memis, 2017). Bu bağlamda argümantasyon sürecinin öğrencilerin kendilerine olan güvenlerine, duyuşsal özelliklerine ve öğrenmelerine birçok olumlu etkisinin olduğu söylenebilir.

Öğretim programlarında önerilen veya uygulanan yaklaşım ve yöntemlerin teknoloji ile desteklenmesi önerilmektedir. Benzer olarak argümantasyona dayalı öğrenmenin de web destekli olarak işlenmesi önem kazanmaktadır. Bu duruma paralel olarak katılımcıların teknolojik pedagojik alan bilgileri öz güvenlerinin artacağı düşünülmektedir.

\section{STEM Eğitimi (Fen, Teknoloji, Mühendislik ve Matematik)}

STEM, gerçek hayatla ilişkilendirilmiş konuların veya problemlerin fen, teknoloji, matematik ve mühendislik disiplinlerine entegre edilerek bütünleşik bir şekilde öğretilmesidir (Bakırcı \& Kutlu, 2018; Çakır \& Ozan, 2018; Özcan, \& Koca, 2019). STEM, disiplinleri bir araya getiren, etkili ve kaliteli öğrenmeyi sağlayan, bilgiyi günlük hayata entegre eden, üst düzey düşünmeyi kapsayan bir yaklaşımdır (Yıldırım \& Altun, 2015). STEM; fen, teknoloji, mühendislik ve matematik alanlarındaki öğretme ve öğrenmeyi ifade etmekle birlikte, okul öncesi eğitimden doktora eğitimine kadar tüm sınıf seviyelerindeki faaliyetleri içermektedir (Gonzalez \& Kuenzi, 2012). Bu bağlamda STEM tüm eğitim kademelerinde uygulanabilecek disiplinler arası bir yaklaşım olarak ifade edilebilir.

STEM çeşitli okuryazarlık becerilerini geliştirdiğinden, bireylerin kariyere hazırlanmaları yolunda bir köprü oluşturmaktadır (Wu, Marsono, \& Khasanah, 2019). Çünkü STEM, süreç sonunda ülke ekonomisine katkı sağlayabilecek ürünlerin ortaya konulduğu bir yaklaşımdır (Çevik \& Abdioğlu, 2018). Bu amaçla STEM içerisinde; tüm STEM disiplinleri yer almalı ve bununla birlikte STEM mesleklerinde 
teknik ile kişisel becerilere sahip bir işgücü için ve 21. yüzyılın zorluklarının üstesinden gelmek üzere hazırlanan STEM okuryazarlığı için daha fazla çeşitlilik olması gerekmektedir (Bybee, 2010). Zaten STEM eğitim yaklaşımı olarak kullanılan tanımda yaşadığımız yüzyılın gerektirdiği; 21. yüzyıl becerilerine sahip, üretken, girişimci, inovatif bireyler yetiştirebilmek vurgulanmaktadır (Barış \& Ecevit, 2019).

STEM eğitiminin hem birçok disiplini içermesi hem de farklı becerilere yönelik olmasına paralel olarak öğrenciler üzerinde birçok olumlu katkısı bulunmaktadır. STEM, kişilerin rekabet yeteneğinin ve STEM okuryazarlığının gelişimini sağlayan disiplinler arası bir yaklaşımdır (Bircan, Köksal, \& Cımbız, 2019). Bunun yanında STEM eğitimi yenilikçi becerilerin gelişmesine katkı sağlamaktadır (Şahin \& Kabasakal, 2018). STEM eğitimi, öğrencilere üst düzey düşünme becerisi, yaratıcılık becerisi, bir problemin birden fazla çözüm yolu olabileceğini anlama, cesaretli olma, öz güvenli olma, işbirliği yapabilme ve etkili iletişim kurabilme becerileri kazandırmaktadır (Deveci, 2018). STEM eğitimi ile öğrencilere bir disiplin öğretilirken diğer disiplinlerle de bağlantı kurularak, onların diğer disiplinleri de öğrenmesi sağlanmaktadır (Yıldırım \& Türk, 2018). Sonuç olarak öğrencileri keşif, sorgulama ve problem çözme deneyimleriyle doğal dünya hakkında öğrenmeye teşvik eden bütünleştirici, disiplinler arası bir STEM eğitiminin önemi açıktır (Asghar, Ellington, Rice, Johnson, \& Prime, 2012). STEM eğitimi ile hem günlük yaşamla ilişkili konuların ele alınması hem de disiplinler arası ilişki kurulmasından dolayı öğrenme daha anlamlı olmaktadır. Bu duruma paralel olarak öğrenmeye yönelik öz yeterlik olumlu yönde gelişmektedir. Bunun yanında STEM eğitimi fen, matematik, mühendislik ve teknoloji alanlarını içermektedir. Bu bağlamda STEM eğitiminin öğrenilmesi ve derslerin bu şekilde işlenmesine paralel olarak katılımcıların hem bu alanlara yönelik bilgi düzeyleri hem de öz güvenlerinin artması beklenmektedir. Bu duruma paralel olarak katılımcıların TPAB öz güvenlerinin de olumlu yönde gelişeceği düşünülmektedir.

\section{Yöntem}

Bu çalışmada, basit deneysel desen kullanılmıştır. Basit deneysel desen, kontrol grubu olmayan, deneğin veya örneklemin çeşitli değişkenler bakımından gelişiminin takip edildiği araştırmalardır (Çepni, 2018). Çağdaş yaklaşımlar eğitiminin öğretmen adaylarının fen öğretimine yönelik öz yeterliklerine ve TPAB öz güvenlerine etkisi araştırıldığından deneysel desen ve öğretilen yöntem tek grup üzerinden araştırıldığından basit deneysel desenin kullanılması uygun görülmüştür.

\section{Çalışma Grubu}

2018 Ocak ayında gerçekleştirilen araştırmada deneysel desen seçilmesine paralel olarak uygun örneklem seçimine gidilerek çalışma grubu oluşturulmuştur. Çalışma grubunu, TUBiTAK 2229 Bilimsel Etkinlikleri Destekleme Programı kapsamında yürütülen "Fen Bilgisi Öğretmen Adaylarına Yönelik Fen Öğretiminde Çağdaş Yaklaşımlar Eğitimi" projesinde seçilen fen bilgisi öğretmen adayları oluşturmaktadır. Bu bağlamda çalışmada yer alan katılımcı öğretmenlerin seçiminde amaçlı örnekleme yöntemi kullanılmıştır. Öğretmenlerin seçiminde; daha önceden bu projeye benzer bir çalışmada yer alıp almama durumu, akademik not ortalamaları, projede yer almak istediklerine ilişkin açıklamaları gibi bir dizi kriter dikkate alınmıştır. Proje kapsamında belli bir süre başvurular alınmış ve projeye 268 öğretmen adayı başvurmuştur. Başvuran adayların akademik not ortalamaları sıralanmış ve daha önce benzer bir projede yer almayan katılımcılar arasından tercihler yapılııştır. Bu süreçte katıımcıların farklı bölgelerdeki farklı üniversitelerde öğrenimlerine devam etmelerine özen gösterilmiştir. Sonuç olarak Türkiye'nin 7 farklı coğrafi bölgesindeki 29 farklı üniversitede öğrenim görmekte olan fen bilgisi öğretmen adayları belirlenmiştir. Çalışmanın katıımcı grubunu 3. ve 4. sınıfa devam eden 30 fen bilgisi öğretmen adayı oluşturmaktadır.

\section{Deney Süreci}

Deneysel uygulama süreci 8 gün ve günde 8 'er saatlik eğitimlerden oluşmakta olup 64 ders saati şeklinde gerçekleşmiştir. Bu eğitimler, ulusal / uluslararası düzeyde yayınladıkları bilimsel çalışmalarla konuya ilişkin yetkinliklerini kanıtlamış alanında uzman 11 öğretim üyesi tarafından 
verilmiştir. Uygulamalar bir otelde yer alan toplantı salonunda gerçekleştirilmiştir. İlk gün öncelikle eğitim süreci, amacı ve kapsamı hakkında katılımcılara bilgi verilmiştir. Daha sonra drama alanında uzman bir öğretim üyesi tarafından, öğretmen adaylarının tanışma ve kaynaşmasını sağlamak amacıyla drama etkinliği gerçekleştirilmiştir. Ardından fen bilgisi eğitiminde uzman bir öğretim üyesi tarafından fen bilimleri öğretim programı tanıtılmıştır. İkinci gün, program tanıtımı özellikle önerilen öğretim yöntemleri üzerine odaklanılmıştır. Ardından araştırma-sorgulamaya dayalı öğrenme konusunda uzman bir öğretim üyesi tarafından öncelikle araştırma-sorgulamaya genel bakış sağlamak için teorik bir sunum gerçekleştirilmiş ve araştırma-sorgulama sürecine ilişkin uygulamalar yapılmıştır. Üçüncü gün, araştırma-sorgulamaya dayalı öğrenme konusunda başka bir uzman öğretim üyesi araştırmasorgulama sürecinde teknoloji entegrasyonu ve değerlendirme şekilleri üzerinde teorik ve uygulamalı eğitimler gerçekleştirmiştir. Ayrıca yönteme ilişkin yurt dışı uygulama örnekleri gösterilerek öğretmen adaylarının daha fazla etkinlik görmeleri sağlanmıştır. Daha sonra fen eğitiminde uzman bir akademisyen tarafından yönteme ilişkin uygulamalar gerçekleştirilmiştir. Burada katılımcıların yönteme ilişkin çok fazla sayıda uygulama görmeleri amaçlanmaktadır.

Dördüncü gün, iki uzman akademisyen tarafından öğretmen adaylarıyla birlikte araştırmasorgulamaya dayalı öğrenme ve STEM uygulamaları gerçekleştirilmiştir. Süreç boyunca öğretmen adaylarının sorgulama becerilerini etkin olarak kullanmaları sağlanmıştır. Beşinci gün argümantasyona dayalı öğrenme yöntemi iki öğretim üyesi tarafından sürdürülmüştür. Öncelikle argümantasyonun önemi ve süreçleri hakkında bilgi verilmiş, öğrenme ortamı oluşturularak örnek etkinlikler gerçekleştirilmiştir. Daha sonra teknoloji entegrasyonu üzerinde durulmuş ve çeşitli araçlarla uygulamalar yapılmıştır. Son olarak ise farklı ülkelerdeki uygulamalar sunularak katılımcıların farklı ülkelerde durumu görmeleri sağlanmıştır. Altıncı güne gelindiğinde, argümantasyona dayalı öğrenme ile ilgili örnek uygulamalar ile güne başlanmıştır. Özellikle web araçları ile grup şeklinde uygulamalar gerçekleşmiştir. Daha sonra fen derslerinde argümantasyona dayalı öğrenme yönteminde sosyobilimsel konuların nasıl ele alınabileceğine ilişkin küçük ve büyük grup tartışması uygulamaları yapılmıştır. Ardından uygulamalı olarak fen ve sanat etkinlikleri gerçekleştirilmiştir. Yedinci gün, STEM alanında uzman bir akademisyen tarafından STEM eğitiminin sınıf ortamına entegrasyonuna ilişkin teorik ve uygulamalı eğitimler verilmiştir. Bu süreçte örnek STEM etkinlikleri gruplar halinde öğrenciler tarafından gerçekleştirilmiştir. Daha sonra alanında uzman bir öğretim üyesi tarafından robotik uygulamalara ilişkin teorik bilgi verilmiş ve legolarla uygulamalar gruplar halinde yapılmıştır. Tüm bu süreçte STEM eğitimine ilişkin farklı örneklerin sunulmasına özen gösterilmiştir. Son gün ise STEM etkinlikleri devam ederek süreç tamamlanmıştır.

Uygulama süreci; fen bilimleri öğretim programının vizyonu, ünite yapıları ve kazanımları, fen eğitiminde araştırma-sorgulamaya dayalı öğrenme, argümantasyona dayalı öğrenme, STEM eğitimi ile fen dersinde teknoloji kullanımı konularını kapsayan odakta gerçekleşmiştir. Eğitimler, fen bilgisi öğretmen adaylarıyla konuya ilişkin teorik bilgilerin paylaşıımasının yanında öğretilen konuya yönelik yerinde ve zamanında etkin uygulamalı öğretimlerin verilmesi şeklinde tamamlanmıştır.

\section{Veri Toplama Araçları}

Veri toplama aracı olarak ön-test ve son-test olarak “Fen Öğretimine Yönelik Öz yeterlik Ölçeği” ve "Teknolojik Pedagojik Alan Bilgisi Öz Güven Ölçeği” kullanılmıştır. Fen öğretimine yönelik öz yeterlik ölçeği 1990 yılında Riggs ve Enochs tarafından geliştirilmiş olup Özkan, Tekkaya ve Çakıroğlu (2002) tarafından Türkçe'ye uyarlanmıştır. Ölçek $5^{\prime} l i$ likert şeklinde 23 maddeden oluşmaktadır. Ölçek, fen öğretiminde kişisel öz yeterlik inancı ( 13 madde) ve fen öğretiminde sonuç beklentisi ( 10 madde) olmak üzere iki faktörden oluşmaktadır. Özkan ve diğerleri tarafından fen öğretiminde kişisel öz yeterlik inancı için güvenirlik değeri .79 ve fen öğretiminde sonuç beklentisi için güvenirlik değeri .86 olarak bulunmuştur. Bu çalışma kapsamında ise Cronbach Alpha güvenilirlik değeri .82 olarak bulunmuştur. Ayrıca ölçeğin kapsam ve görünüş geçerliliğini sağlayabilmek için uzman görüşüne sunulmuş, ölçek maddelerinin ölçülmek istenen amaca uygun olduğu sonucuna ulaşılmıştır. 
Çalışmada kullanılan bir diğer veri toplama aracı olan Teknolojik Pedagojik Alan Bilgisi Öz Güven Ölçeği ise; Graham, Burgoyne, Cantrell, Smith ve Harris (2009) tarafından geliştirilmiş ve Cronbach Alpha güvenirlik değeri .95 olarak bulunmuştur. Ölçek Timur ve Taşar (2011) tarafından Türkçe'ye uyarlanmıştır. Ölçek 5'li likert şeklinde olup 31 maddeden oluşmaktadır. Ölçekte; teknolojik pedagojik alan bilgisi (TPAB), teknolojik pedagojik bilgi (TPB), teknolojik alan bilgisi (TAB) ve teknolojik bilgi (TB) şeklinde dört boyut yer almaktadır. Ölçeğin geneli için Cronbach Alpha güvenirlik katsayısı .92 bulunmuştur. Ayrıca ölçeğin DFA analizi sonunda $\chi 2 / d f=2.86(p=.000), N F I=.87$ ve $R M S E A=.069$ olarak belirlenmiştir. Bu çalışma kapsamında ise Cronbach Alpha güvenilirlik değeri .89 olarak hesaplanmıştır. Bu süreçte kullanılan ölçek iki uzman tarafından kapsam ve görünüş geçerliliği açısından incelenmiştir. İncelemeler sonucunda ölçeğin istenilen özellikleri ölçtüğü sonucuna varılmıştır.

\section{Veri Analizi}

Çalışmadan elde edilen veriler SPSS paket programı yardımıyla analiz edilmiştir. Bu süreçte olumlu maddeler aynı şekilde girilirken, olumsuz maddeler ters çevrilerek sistemde yer almıştır. Daha sonra verilerin normal dağıım gösterip göstermediğini belirmek için basıklık ve çarpıklık değerlerine bakılmıştır. "Fen Öğretimine Yönelik Öz Yeterlik Ölçeği" için çarpıklık değeri .437 ve basıklık değeri .806 olarak hesaplanmıştır. "Teknolojik Pedagojik Alan Bilgisi Öz Güven Ölçeği"ne ilişkin ise çarpıklık değeri .336 ve basıklık değeri .924 olarak bulunmuştur. Tüm değerler -1 ile +1 arasında yer aldığından verilerin normal dağıldığı söylenebilir. Bu duruma paralel olarak verilerin analizinde ilişkili örneklemler t-testi yapılması uygun görülmüştür. Bu çalışmada güvenirliği ve geçerliği arttırabilmek için, grubun heterojen olarak dağıldığı ve farkı üniversitelerdeki öğretmen adayları tercih edildiği, uygulama koşullarının kontrol altına alındığı söylenebilir.

\section{Bulgular}

Çalışmanın bu bölümünde çağdaş yaklaşımlar eğitiminin öğretmen adaylarının fen öğretimine yönelik öz yeterliklerindeki farklılığa ilişkin bulgular ile çağdaş yaklaşımlar eğitiminin fen bilimleri öğretmen adaylarının teknolojik pedagojik alan bilgileri (TPAB) özgüvenlerindeki farklılığa ilişkin bulgular yer almaktadır.

\section{Çağdaş Yaklaşımlar Eğitiminin Öğretmen Adaylarının Fen Öğretimine Yönelik Öz Yeterliklerindeki Farklılığa ilişkin Bulgular}

Bu çalışmada; çağdaş yaklaşımlar eğitiminin öğretmen adaylarının fen öğretimine yönelik öz yeterliklerindeki farklıı̆ı belirlemek için bağımlı gruplar t-testi kullanılmıştır. Öğretmen adaylarının fen öğretimine yönelik öz yeterliklerine ilişkin ön-test ve son-test puanları t-testi sonuçları Tablo 1'de verilmiştir.

Tablo 1.

Öğretmen Adaylarının Fen Öğretimine Yönelik Öz Yeterliklerine Ilişkin Ön-test ve Son-test Puanları t-Testi Sonuçları

\begin{tabular}{lcccccc}
\hline Test & $\mathbf{N}$ & $\overline{\mathbf{X}}$ & SS & SD & $\mathbf{t}$ & $\mathbf{p}$ \\
\hline Ön-test & 30 & 73.06 & 8.21 & \multirow{2}{*}{58} & -0.70 & \multirow{2}{*}{.944} \\
Son-test & 30 & 73.20 & 6.38 & & & \\
\hline
\end{tabular}

Tablo 1'de görüldüğü üzere, öğretmen adaylarının fen öğretimine yönelik öz yeterlik ön-test ve sontest puanlarında anlamlı bir farklılık meydana gelmemiştir $(t(58)=-0.70, p>05)$. Bu bağlamda uygulanan çağdaş yaklaşımlar eğitiminin öğretmen adaylarının fen öğretimine yönelik öz yeterliklerine belirgin bir artışa neden olmadığı söylenebilir. Öğretmen adaylarının ön-test puanlarının ortalaması 73.06 iken son-test puanlarının 73.20 olduğu anlaşılmıştır. Bu noktada katılımcıların ortalama puanlarında da belirgin bir artış olmadığı ifade edilebilir. Bununla birlikte ölçekten alınabilecek en düşük puan 23 ve en yüksek puanın 115 olduğu düşünüldüğünde, öğretmen adaylarının fen öğretimine yönelik öz 
Ümmühan Ormancı, Sevinç Kaçar, Erkan Özcan, A. Günay Balım - Uluslararası Eğitim Programlar ve Öğretim Çalışmaları Dergisi, 10(1), 2020, 1-28

yeterliklerinin orta ve iyi olduğu söylenebilir. Öğretmen adaylarının fen öğretimine yönelik öz yeterlik ölçeğinin alt boyutlarına ilişkin ön-test ve son-test puanları t-testi sonuçları Tablo 2'de gösterilmiştir.

Tablo 2.

Öğretmen Adaylarının Fen Öğretimine Yönelik Öz Yeterlik Ölçeğinin Alt Boyutlarına Ilişkin Ön-test ve Son-test Puanları t-Testi Sonuçları

\begin{tabular}{|c|c|c|c|c|c|c|c|}
\hline Alt Boyutlar & Test & $\mathbf{N}$ & $\overline{\mathbf{X}}$ & SS & SD & $\mathbf{t}$ & p \\
\hline Fen Öğretiminde Kişisel Öz & Ön-test & 30 & 37.20 & 5.79 & \multirow{2}{*}{58} & \multirow{2}{*}{.953} & \multirow{2}{*}{.345} \\
\hline Yeterlik İnancı & Son-test & 30 & 36.07 & 2.97 & & & \\
\hline Fen Öğretiminde Sonuç & Ön-test & 30 & 35.87 & 3.97 & \multirow{2}{*}{58} & \multirow{2}{*}{-1.063} & \multirow{2}{*}{.292} \\
\hline Beklentisi & Son-test & 30 & 37.13 & 5.17 & & & \\
\hline
\end{tabular}

Tablo 2 incelendiğinde öğretmen adaylarının fen öğretiminde kişisel öz yeterlik inancı $(t(58)=.958$, $p>.05)$ ve fen öğretiminde sonuç beklentisi $(t(58)=-1.063, p>.05)$ ön-test ve son-test puanları arasında anlamlı farklılık olmadığı anlaşılmıştır. Uygulanan çağdaş yaklaşımlar eğitiminin öğretmen adaylarııı fen öğretimine yönelik öz yeterliklerinin alt boyutlarında belirgin bir artışa neden olmadığı söylenebilir.

\section{Çağdaş Yaklaşımlar Eğitiminin Fen Bilimleri Öğretmen Adaylarının Teknolojik Pedagojik Alan Bilgileri (TPAB) Özgüvenlerindeki Farklılığa ilişkin Bulgular}

Çalışmada çağdaş yaklaşımlar eğitimin öğretmen adaylarının TPAB öz güvenlerindeki farklılı̆ı̆ belirlemek için bağımlı gruplar t-testi kullanılmıştır. Fen bilgisi öğretmen adaylarının TPAB öz güvenlerine ilişkin ön-test ve son-test puanları t-testi sonuçları Tablo 3’te verilmiştir.

Tablo 3.

Öğretmen Adaylarının TPAB Öz Güvenlerine ilişskin Ön-test ve Son-test Puanları t-Testi Sonuçları

\begin{tabular}{lcccccc}
\hline Test & $\mathbf{N}$ & $\overline{\mathbf{X}}$ & $\mathbf{S S}$ & SD & $\mathbf{t}$ & $\mathbf{p}$ \\
\hline Ön-test & 30 & 130.77 & 12.97 & \multirow{2}{*}{58} & \multirow{2}{*}{3.35} & \multirow{2}{*}{001} \\
Son-test & 30 & 141.90 & 12.80 & & & \\
\hline
\end{tabular}

Tablo 3'te görüldüğü gibi, fen bilgisi öğretmen adaylarının TPAB öz güvenleri ön-test ve son-test puanlarında anlamlı bir farklılık olduğu tespit edilmiştir $(t(58)=-3.35, p<.05)$. Uygulanan çağdaş yaklaşımlar eğitiminin öğretmen adaylarının TPAB öz güvenlerinde son-test lehine anlamlı bir artışa sebep olduğu söylenebilir. Öğretmen adaylarının ön-test puanlarının ortalaması 130.77 iken son-test puanlarının 141.90 olduğu anlaşılmıştır. Bu noktada öğretmen adaylarının TPAB öz güvenlerinde belirgin şekilde bir artma olduğu ve bunun verilen eğitime paralel olduğu ifade edilebilir. Ayrıca TBAP öz güvenleri ölçeğinden alınabilecek en düşük puan 31 , en yüksek puan 155 'dir ve öğretmen adaylarının son-test ortalamaları 142 olduğundan, öğretmen adaylarının TPAB öz güvenlerinin yüksek olduğu söylenebilir. Öğretmen adaylarının TPAB öz güven ölçeğinin alt boyutlarına ilişkin ön-test ve son-test puanları t-testi sonuçları Tablo 4'te yer almaktadır.

Tablo 4.

Öğretmen Adaylarının TPAB Öz Güven Ölçeğinin Alt Boyutlarına Illişkin Ön-test ve Son-test Puanları t-Testi Sonuçları

\begin{tabular}{|c|c|c|c|c|c|c|c|}
\hline Alt Boyutlar & Test & $\mathbf{N}$ & $\overline{\mathbf{X}}$ & SS & SD & $\mathbf{t}$ & $\mathbf{p}$ \\
\hline \multirow{2}{*}{ TPAB } & Ön-test & 30 & 34.60 & 3.39 & \multirow{2}{*}{58} & \multirow{2}{*}{-3.502} & \multirow{2}{*}{.001} \\
\hline & Son-test & 30 & 37.50 & 3.00 & & & \\
\hline \multirow{2}{*}{ TPB } & Ön-test & 30 & 29.73 & 3.55 & \multirow{2}{*}{58} & \multirow{2}{*}{-2.593} & \multirow{2}{*}{.012} \\
\hline & Son-test & 30 & 32.13 & 3.62 & & & \\
\hline \multirow{2}{*}{ TAB } & Ön-test & 30 & 21.57 & 2.46 & \multirow{2}{*}{58} & \multirow{2}{*}{-2.524} & \multirow{2}{*}{.014} \\
\hline & Son-test & 30 & 23.07 & 2.13 & & & \\
\hline \multirow{2}{*}{ TB } & Ön-test & 30 & 44.87 & 5.84 & \multirow{2}{*}{58} & \multirow{2}{*}{-2.852} & \multirow{2}{*}{.006} \\
\hline & Son-test & 30 & 49.20 & 5.93 & & & \\
\hline
\end{tabular}

Tablo 4 incelendiğinde ölçeğin alt boyutları olan TPAB ( $t(58)=-3.502 p<.05)$, TPB $(t(58)=-2.593$, $p<.05)$, TAB $(t(58)=-2.524, p<.05)$ ve TB $(t(58)=-2.852, p<.05)$ ön-test ve son-test puanlarında son-test lehine anlamlı farklılık olduğu anlaşılmıştır. Bu noktada uygulanan çağdaş yaklaşımlar eğitiminin 
öğretmen adaylarının TPAB öz güven ölçeğinin her bir alt boyutunda anlamlı bir artışa neden olduğu ifade edilebilir.

\section{Tartışma, Sonuç ve Öneriler}

Mevcut çalışmadan elde edilen bulgulara göre öğretmen adaylarının fen öğretimine yönelik öz yeterlik ön-test ve son-test puanlarında anlamlı bir farklılık olmadığı anlaşılmıştır. Benzer olarak ölçeğin alt boyutları olan öğretmen adaylarının fen öğretiminde kişisel öz yeterlik inancı ve fen öğretiminde sonuç beklentisi puanlarında da anlamlı bir artış meydana gelmemiştir. Bu noktada çağdaş yaklaşımlar eğitiminin fen bilgisi öğretmen adaylarının fen öğretimine yönelik öz yeterliklerini geliştirmede önemli bir farklılığa neden olmadığı söylenebilir. Buna karşın alanyazında araştırma-sorgulamaya dayalı öğrenmenin fen bilgisi öğretmen adaylarının akademik veya fen öğretimine yönelik öz yeterliklerini olumlu yönde geliştirdiği sonucuna ulaşılmıştır (Kayacan \& Selvi, 2017; Şensoy \& Aydoğdu, 2008). Ayrıca argümantasyon tabanlı sorgulayıcı araştırma yönteminin fen bilgisi öğretmen adaylarının fen öğretiminde öz yeterlik inancı alt boyutlarında (fen öğretiminde öz yeterlik inancı ve fen öğretiminde sonuç beklentisi) önemli bir etkisinin olduğu belirlenmiştir (Eymur \& Çetin, 2017). Oluşturmacı yaklaşımın (Kutluca \& Aydın, 2016), probleme dayalı öğrenme yaklaşımının (Yaman \& Yalçın, 2005) ve deney için animasyon, simülasyon kullanımının (Yener ve diğerleri, 2012) katılımcıların fen/fizik öğretimine yönelik öz yeterlik inanç düzeylerini geliştirdiği sonuçlarına ulaşılmıştır. Buna karşın mevcut çalışmaya paralel olarak alanyazında farklı çağdaş öğrenme yaklaşımlarının derse yönelik öz yeterlik üzerinde etkisinin olmadığına ilişkin araştırmalara rastlanmaktadır. Yapılan çalışmalarda; proje tabanlı öğretim uygulamalarının fen bilgisi öğrencilerinin fiziğe yönelik öz yeterliklerine (Çıbık, İnce, \& Kayacan, 2016) ve probleme dayalı öğrenmenin katılımcıların derse yönelik öz yeterlik inanç düzeyleri üzerine (Gürlen, 2011; Yurdatapan, 2013) etkisinin olmadığını belirlemiştir. Mevcut çalışmada elde edilen bu sonuç, beklenmeyen bir durumdur. Çünkü alınan eğitimlerin özellikle uygulama içeren ve katıımcıların kendilerinin etkin olarak sürece katıldıkları eğitimlerin öz yeterlikleri olumlu yönde etkileyeceği düşünülmektedir. Bu uygulamalarda genellikle öğretmen adaylarının aktif olduğu ve etkinlikleri kendilerinin yaptıkları düşünüldüğünde, öz yeterliklerinin gelişmesi beklenmektedir. Alanyazın da bu durumu desteklemektedir. Fen öğretimine yönelik öz yeterlikleri öğretmen merkezliden öğrenci merkezli öğretim modeline geçtikçe artmaktadır (Feyzioğlu, Feyzioğlu, \& Küçükçıngı, 2014). Buna karşın bu çalışmada gelişme olmamasının nedeninin, eğitimin yoğunlaştırılmış kısa süreli olmasından kaynaklandığı düşünülmektedir. Saat olarak bakıldığında uzun olarak görünen bir eğitim olmasına rağmen gün sayısı bağlamında kısa sürelidir. Bu bağlamda ileride yapılacak çalışmalarda yoğunlaştırma yerine daha uzun süreli programların yapılmasının daha etkili olabileceği düşünülmektedir.

Mevcut çalışmada fen bilgisi öğretmen adaylarının fen öğretimine yönelik öz yeterlik ölçeğinden aldıkları ortalama puan $73^{\prime}$ dür. Bu noktada öğretmen adaylarının fen öğretimine yönelik öz yeterliklerinin orta ve iyi düzeyde olduğu söylenebilir. Alanyazında yapılan çalışmalarda biyoloji öğretmen adaylarının biyoloji öğretiminde öz yeterlik inançlarının (Gerçek, Yılmaz, Köseoğlu, \& Soran, 2006) ve fen bilgisi öğretmen adaylarının fen öğretimine yönelik öz yeterliklerinin yüksek (Denizoğlu, 2008) düzeyde olduğu tespit edilmiştir. Berkant ve Ekici'nin (2007) çalışmalarında ise öğretmen adaylarının fen öğretiminde öz yeterlik inançlarının orta düzeyde olduğu belirlenmiştir. Şenler (2017) ise yaptığı çalışmada öğretmen adaylarının fen öğretimine yönelik öz-yeterlik inanç puanlarının ortalamanın çok üstünde olduğu sonucuna ulaşmıştır. Öğretmen adaylarının fen öğretimine yönelik öz yeterliklerinin orta veya yükseğe yakın olmasındaki en önemli etmen üniversite sınıf düzeylerinin yüksek olmasıdır. Benzer olarak Yaman ve diğerleri (2004) çalışmalarında sınıf seviyesi yükseldikçe fen öğretimine yönelik öz yeterlik inanç düzeyinin de arttığını belirtmektedir. Bu durumun, öğretmen adaylarının üniversitede fen öğretimine yönelik birçok ders görmelerine paralel olarak fen öğretimine yönelik inançlarının olumlu yönde gelişmesinden kaynaklandığı düşünülmektedir. Öğretmen adaylarının fen öğretimine yönelik öz yeterliklerinin orta ve yüksek olmasındaki bir diğer etmenin ise akademik başarılarının yüksek olmasından kaynaklandığı düşünülmektedir. Akbaş ve Çelikkaleli'nin (2006) belirttiği gibi akademik başarı arttıkça, fen öğretiminde öz yeterlik inancı da artmaktadır. Bu 
duruma paralel olarak katılımcı grubun başarı ortalamaları yüksek olmasına paralel olarak öz yeterliklerinin yüksek olduğu düşünülmektedir.

Mevcut çalışmada, çağdaş yaklaşımlar eğitiminin fen bilgisi öğretmen adaylarının TPAB öz güvenlerini olumlu yönde geliştirdiği anlaşılmıştır. Benzer olarak tüm alt boyutlarda da son-test lehine anlamlı farklılık olduğu belirlenmiştir. Bu noktada uygulanan çağdaş yaklaşımlar eğitiminin öğretmen adaylarının TPAB öz güvenlerini geliştirmede önemli bir farklılığa neden olduğu söylenebilir. Alanyazında farklı öğretim yöntemleri ile yapılan çalışmalarda benzer sonuçlara ulaşıldığı söylenebilir. Kılıç (2015) çalışmasında TPAB temelli harmanlanmış öğrenme ortamının fen bilgisi öğretmen adaylarının temel astronomi konularına ilişkin TPAB'larını olumlu yönde geliştirdiğini ifade etmiştir. Tatlı, Akbulut ve Altınışık (2016) ise çalışmalarında Web 2.0 araçlarının eğitim amaçlı kullanımının öğretmen adaylarının TPAB öz güven düzeylerinde anlamlı bir artışa sebep olduğu sonucuna ulaşmışlardır. Cesur Özkara, Yavuz Konokman ve Yanpar Yelken (2018) çalışmalarında teknolojiye erişimin ve teknolojiye ilginin öğretmenlerinin TPAB öz güven düzeylerinde farklılaşma oluşturan bir değişken olduğu sonucuna ulaşmışlardır. Anlaşılacağı üzere öğretmen adaylarııın TPAB öz güvenlerinin gelişmesinde en önemli etmenlerden biri hem teknolojinin hem öğretim yöntemlerinin etkili olarak süreçte kullanılmasıdır. Yapılan bu çağdaş yaklaşımlar eğitimi uygulamalarında da hem yöntemler bilgi ve uygulama açısından derinlemesine işlenmiş hem de teknoloji entegrasyonu üzerinde ayrıntılı olarak durulmuştur. Bu duruma paralel olarak öğretmen adaylarının TPAB öz güvenlerinin yükselmesi istenen ve beklenen bir sonuçtur. Bu bağlamda üniversite eğitimleri süresince teknolojinin entegrasyonuna daha fazla önem verilmesi gerektiği düşünülmektedir. Benzer olarak Korucu, Usta ve Atun (2017) sürece teknolojinin ilave edilmesindeki aksaklıkların en aza çekilebilmesi için öğretmenlerin TPAB çerçevesine göre eğitilmesinin önemli olduğunu belirtmektedirler.

Mevcut çalışmada fen bilgisi öğretmen adaylarının TBAP öz güvenleri ölçeğinden aldıkları ortalama puan 142'dir. Bu bağlamda öğretmen adaylarının TPAB öz güvenlerinin yüksek olduğu söylenebilir. Benzer olarak alanyazında fen bilgisi öğretmenlerinin TPAB öz güven düzeylerinin yüksek olduğu sonuçlarına ulaşılmıştır (Bağdiken \& Akgündüz, 2018; Cesur Özkara ve diğerleri, 2018; Meriç, 2014). Yapılan tüm çalışmalarda TPAB öz güvenleri yüksek olmasına rağmen, uygulamalarda eksiklikler ve sorunlar olduğu söylenebilir. Bu konu üzerine odaklanılması ve alanyazında buna ilişkin nicel ile nitel verilerle sürecin ayrıntılı olarak araştırıldığı çalışmalara ihtiyaç duyulduğu söylenebilir.

Çalışmadan elde edilen sonuçlara göre; uygulanan çağdaş yaklaşımlar eğitimi öğretmen adaylarının fen öğretimine yönelik öz yeterliklerinde anlamlı bir farklılığa neden olmazken, teknolojik pedagojik alan bilgileri öz güvenlerinde anlamlı bir farklılığa neden olduğu anlaşılmıştır. Her iki değişken bağlamında da verilen eğitimin; hem uygulamaya dönük olması hem de teknoloji desteği içermesi, katııımcıların fen öğretimine yönelik becerilerini dolayısıyla özgüven ve öz yeterliklerini olumlu yönde geliştirdiği düşünülmektedir. Bu duruma paralel olarak benzer eğitimlerin yapılmasının öğretmen adayları ve öğretmenler açısından önemli olacağı önerisinde bulunulabilir. Ancak gerçekleştirilen uygulamada ders saati olarak yoğun bir program uygulanmasına karşın, kısa süreli zaman dilimini kapsamasından dolayı bazı aksaklıklar yaşanmıştır. Bu bağlamda benzer eğitimlerin haftalara yayılarak verilmesinin daha uygun olacağı ve buna yönelik yapılacak akademik çalışmaların alanyazın açısından önemli olacağı ifade edilebilir. Ayrıca eğitimin etkililiği benzer değişkenler için nicel veri toplama araçlarının yanında nitel veri toplama araçları kullanılarak da yapılabileceği önerisinde bulunulabilir.

\section{Teşekkür}

Bu çalışma, TÜBITAK-2229- Bilimsel Etkinlikleri Destekleme Programı tarafından desteklenen "Fen Bilgisi Öğretmen Adaylarına Yönelik Fen Öğretiminde Çağdaş Yaklaşımlar Eğitimi" projesinin bir parçasıdır. Bu araştırmanın özeti IX. Uluslararası Eğitimde Araştırmalar Kongresi'nde sözlü sunum olarak sunulmuştur. 


\section{References}

Abdi, A. (2014). The effect of inquiry-based learning method on students' academic achievement in science course. Universal Journal of Educational Research, 2(1), 37-41.

Akbaş, A., \& Çelikkaleli, Ö. (2006). Sınıf öğretmeni adaylarının fen öğretimi öz yeterlik inançlarının cinsiyet, öğrenim türü ve üniversitelerine göre incelenmesi. Mersin Üniversitesi Eğitim Fakültesi Dergisi, 2(1), 98-110.

Apedoe, X. S., Walker, S. E., \& Reeves, T. C. (2006). Integrating inquiry-based learning in to undergraduate geology. Journal of Geoscience Education, 54(3), 414-421.

Asghar, A., Ellington, R., Rice, E., Johnson, F., \& Prime, G. M. (2012). Supporting STEM education in secondary science contexts. Interdisciplinary Journal of Problem-Based Learning, 6(2), 85-125.

Azar, A. (2011). Türkiye'deki öğretmen eğitimi üzerine bir söylem: Nitelik mi, nicelik mi. Yükseköğretim ve Bilim Dergisi, 1(1), 36-38.

Bağdiken, P., \& Akgündüz, D. (2018). Fen bilimleri öğretmenlerinin teknolojik pedagojik alan bilgisi özgüven düzeylerinin incelenmesi. Gazi Üniversitesi Eğitim Fakültesi Dergisi, 38(2), 535-566.

Bakırcı, H., \& Kutlu, E. (2018). Fen bilimleri öğretmenlerinin FeTeMM yaklaşımı hakkındaki görüşlerinin belirlenmesi. Turkish Journal of Computer and Mathematics Education, 9(2), 367-389.

Balçın, M. D., \& Ergün, A. (2019). Fen bilgisi öğretmen adaylarının sahip oldukları teknolojik pedagojik alan bilgisi (TPAB) öz yeterliklerinin belirlenmesi ve çeşitli değişkenlere göre incelenmesi. Mehmet Akif Ersoy Üniversitesi Eğitim Fakültesi Dergisi, 45, 23-47.

Barış, N., \& Ecevit, T. (2019). Özel yetenekli öğrencilerin eğitiminde STEM uygulamaları. Necatibey Eğitim Fakültesi Elektronik Fen ve Matematik Eğitimi Dergisi, 13(1), 217-233.

Bell, T., Urhahne, D., Schanze, S., \& Ploetzner, R. (2010). Collaborative inquiry learning: Models, tools, and challenges. International Journal of Science Education, 32(3), 349-377.

Berkant, H. G., \& Ekici, G. (2007). Sınıf öğretmeni adaylarının fen öğretiminde öğretmen öz yeterlik inanç düzeyleri ile zekâ türleri arasındaki ilişkinin değerlendirilmesi. Çukurova Üniversitesi Sosyal Bilimler Enstitüsü Dergisi, 16(1), 113-132.

Bircan, M. A., Köksal, Ç., \& Cımbız, A. T. (2019). Türkiye'deki STEM merkezlerinin incelenmesi ve STEM merkezi model önerisi. Kastamonu Eğitim Dergisi, 27(3), 1033-1045.

Bybee, R. W. (2010). What is STEM education? Science, 329(5995),996.

Capps, D. K., \& Crawford, B. A. (2013). Inquiry-based Professional development: What does it take to support teachers in learning about inquiry and nature of science? International Journal of Science Education, 35(12), 1947-1978.

Cesur Özkara, E., Yavuz Konokman, G., \& Yanpar Yelken, T. (2018). Eğitimde teknoloji kullanımı hizmet içi eğitimine katılan öğretmenlerin TPAB özgüvenlerinin incelenmesi. Amasya Üniversitesi Eğitim Fakültesi Dergisi 7(2), 371-412.

Çakır, R., \& Ozan, C. E. (2018). FeTeMM etkinliklerinin 7. sınıf öğrencilerinin akademik başarıları, yansıtıcı düşünme becerileri ve motivasyonlarına etkisi. Gazi Üniversitesi Gazi Eğitim Fakültesi Dergisi, 38(3), 1077-1100. 
Ümmühan Ormancı, Sevinç Kaçar, Erkan Özcan, A. Günay Balım - Uluslararası Eğitim Programlar ve Öğretim Çalışmaları Dergisi, 10(1), 2020, 1-28

Çepni, S. (2018). Araştırma ve proje çalışmalarına giriş. Trabzon: Celepler Matbaacılık.

Çevik, M., \& Abdioğlu, C. (2018). Bir bilim kampının 8. sınıf öğrencilerinin STEM başarılarına, fen motivasyonlarına ve üst bilişsel farkındalıklarına etkisinin incelenmesi. Insan ve Toplum Bilimleri Araştırmaları Dergisi, 7(5), 304-327.

Çıbık, A. S., Ince, E., \& Kayacan, K. (2016). Genel fizik laboratuvarı-II dersinde kullanılan proje tabanlı öğretim yönteminin öz-yeterlik, tutum ve başarıya etkisi. Kastamonu Eğitim Dergisi, 24(2), 511534.

Çinici, A., Özden, M., Akgün, A., Herdem, K., Deniz, Ş. M., \& Karabiber, H. L. (2014). Kavram karikatürleriyle desteklenmiş argümantasyon temelli uygulamaların etkinliğinin incelenmesi. Adıyaman Üniversitesi Sosyal Bilimler Enstitüsü Dergisi, 18, 571-596.

Demirel, R. (2016). Argümantasyon destekli öğretimin öğrencilerin kavramsal anlama ve tartışma istekliliklerine etkisi. Kastamonu Eğitim Dergisi, 24(3), 1087-1108.

Demirel, R. (2017). Katı basıncı konusunda argümantasyon etkinliğinin uygulanması. Journal of Inquiry Based Activities, 5(2), 70-90.

Denizoğlu, P. (2008). Fen bilgisi öğretmen adaylarının fen bilgisi öğretimi öz-yeterlik inanç düzeyleri, öğrenme stilleri ve fen bilgisi öğretimine yönelik tutumları arasındaki ilişkinin değerlendirilmesi. Yayımlanmamış yüksek lisans tezi, Adana: Çukurova Üniversitesi.

Deveci, i. (2018). Fen bilimleri öğretmen adaylarının sahip oldukları FeTeMM farkındalıklarının girişimci özellikleri yordama durumu. Kastamonu Eğitim Dergisi, 26(4), 1247-1256.

Duran, M. (2015). Araştırmaya dayalı öğrenme yaklaşımına dayalı etkinliklerin öğrencilerin sorgulayıcı öğrenme becerileri üzerine etkisi. International Journal of Social Science, 32, 399-420.

Duran, M. (2016). The effect of guide material developed based on inquiry-based learning on 6th grade students' competence for learning science. Journal of Theoretical Educational Science, 9(1), 85110.

Duran, M., \& Dökme, í. (2018). Araştırmaya dayalı öğrenme yaklaşımının kavramsal anlama düzeyi ve bazı öğrenme çıktıları üzerine etkisi. Trakya Üniversitesi Eğitim Fakültesi Dergisi, 8(3), 545-563.

Duran, M., Doruk, M., \& Kaplan, A. (2017). Argümantasyon tabanlı olasılık öğretiminin ortaokul öğrencilerinin başarılarına ve kaygılarına etkililiğinin incelenmesi. Eğitimde Kuram ve Uygulama, 13(1),55-87.

Duschl, R. A., \& Osborne, J. (2002). Supporting and promoting argumentation discourse in science education. Studies in Science Education, 38(1) 39-72.

Edelson, D. C., Gordin, D. N., \& Pea, R. D. (1999). Addressing the challenges of inquiry-based learning through technology and curriculum design. Journal of the Learning Sciences, 8(3-4), 391-450.

Eymur, G., \& Çetin, P. S. (2017). Argümantasyon tabanlı sorgulayıcı araştırma yönteminin öğretmen adaylarının fen öğretimi öz yeterlik inancına etkisi. Erzincan Üniversitesi Eğitim Fakültesi Dergisi, 19(3), 36-50.

Fen Bilgisi Öğretmenliği Lisans Programı (2018). Fen Bilgisi Öğretmenliği Lisans Programı. https://www.yok.gov.tr/Documents/Kurumsal/egitim_ogretim_dairesi/Yeni-Ogretmen- 
Ümmühan Ormancı, Sevinç Kaçar, Erkan Özcan, A. Günay Balım - Uluslararası Eğitim Programlar ve Öğretim Çalışmaları Dergisi, 10(1), 2020, 1-28 Yetistirme-Lisans-Programlari/Fen_Bilgisi_Ogretmenligi_Lisans_Programi.pdf 15.11.2019 tarihinde edinilmiştir.

Feyzioğlu, E. Y., Feyzioğlu, B., \& Küçükçıngı, A. (2014). Fen bilgisi öğretmen adaylarının fen öğretimine yönelik zihinsel modelleri, öz yeterlik inançları ve öğrenme yaklaşımları. Ondokuz Mayıs Üniversitesi Eğitim Fakültesi Dergisi, 33(2), 404-423.

Gerçek, C., Yılmaz, M., Köseoğlu, P., \& Soran, H. (2006). Biyoloji eğitimi öğretmen adaylarının öğretiminde öz-yeterlik inançları. Ankara Üniversitesi Eğitim Bilimleri Fakültesi Dergisi, 39(1), 57 73.

Gibson, H. L. (1998, April). Case studies of an Inquiry-based science programs' Impact on students' attitude towards science and interest in science careers. National Association for Research in Science Teaching, 71st, SanDiego, CA.

Gonzalez, H. B., \& Kuenzi, J. J. (2012, August). Science, technology, engineering, and mathematics (STEM) education: A primer. Washington, DC: Congressional Research Service, Library of Congress.

Graham, R. C., Burgoyne, N., Cantrell, P., Smith, L., StClair, L., \& Harris, R. (2009). Measuring the TPACK confidence of in service science teachers. TechTrends, 53(5), 70-79.

Günel, M., Kıngır, S., \& Geban, Ö. (2012). Argümantasyon tabanlı bilim öğrenme (ATBÖ) yaklaşımının kullanıldığı sınıflarda argümantasyon ve soru yapılarının incelenmesi. Eğitim ve Bilim, 37(164), 316-330.

Güneş, Y. İ., Sağdıç, F., \& Şimşek, C. L. (2018). Ortaokul fen bilimleri ders kitaplarındaki etkinliklerin araştırmaya dayalı öğrenmeyi destekleme durumlarının belirlenmesi. Journal of Multidisciplinary Studies in Education, 2(2), 28-38.

Gürlen, E. (2011). Probleme dayalı öğrenmenin öğrenme ürünlerine, problem çözme becerisine, özyeterlik algı düzeyine etkisi. Hacettepe Üniversitesi Eğitim Fakültesi Dergisi, 40(40), 221-232.

Güzel, B. Y., Erduran, S., \& Ardaç, D. (2009). Aday kimya öğretmenlerinin kimya derslerinde bilimsel tartışma (argümantasyon) tekniğini kullanımları. Boğaziçi Üniversitesi Eğitim Dergisi, 26(2), 33-48.

Herdem, K., \& Ünal, ì. (2018). STEM eğitimi üzerine yapılan çalışmaların analizi: Bir meta-sentez çalışması. Marmara Üniversitesi Atatürk Eğitim Fakültesi Eğitim Bilimleri Dergisi, 48, 145-163.

Kavas, A. B., \& Bugay, A. (2009). Öğretmen adaylarının hizmet öncesi eğitimlerinde gördükleri eksiklikler ve çözüm önerileri. Pamukkale Üniversitesi Eğitim Fakültesi Dergisi, 25(25), 13-21.

Kaya, E., Çetin, P. S., \& Erduran, S. (2014). íki argümantasyon testinin Türkçe'ye uyarlanması. Illköğretim Online, 13(3), 1014-1032.

Kayacan, K., \& Selvi, M. (2017). Öz düzenleme faaliyetleri ile zenginleştirilmiş araştırma-sorgulamaya dayalı öğretim stratejisinin kavramsal anlamaya ve akademik öz yeterliğe etkisi. Kastamonu Eğitim Dergisi, 25(5), 1771-1786.

Kennedy, T. J., \& Odell, M. R. L. (2014). Engaging students in STEM education. Science Education International, 25(3), 246-258. 
Ümmühan Ormancı, Sevinç Kaçar, Erkan Özcan, A. Günay Balım - Uluslararası Eğitim Programlar ve Öğretim Çalışmaları Dergisi, 10(1), 2020, 1-28

Kılıç, A. (2015). Teknolojik pedagojik alan bilgisi (TPAB) temelli harmanlanmış öğrenme ortamının fen bilgisi ögretmen adaylarının temel astronomi konularındaki TPAB ve sınıf içi uygulamalarına etkisi. Yayımlanmamış doktora tezi, Elazığ: Fırat Üniversitesi.

Korucu, A. T., Usta, E., \& Atun, H. (2017). Teknolojik pedagojik alan bilgisi üzerine yapılan 2010-2016 dönemi araştırmalardaki eğilimler. Amasya Üniversitesi Eğitim Fakültesi Dergisi, 6(1), 104-133.

Kutluca, A. Y., \& Aydın, A. (2016). Fen bilgisi öğretmen adaylarının öz-yeterlik inançlarının çeşitli değişkenler açısından incelenmesi: Oluşturmacı öğretimin etkisi. Abant İzzet Baysal Üniversitesi Eğitim Fakültesi Dergisi, 16(1), 217-236.

Memis, E. K. (2017). Türkiye'de argümantasyon konusunda gerçekleştirilen tezlerin analizi: Bir metasentez çalışması. Cumhuriyet International Journal of Education, 6(1), 47-65.

Meriç, G. (2014). Fen ve teknoloji öğretmen adaylarının teknolojik pedagojik alan bilgisi (TPABGÖ) konusunda özgüven seviyelerinin belirlenmesi. Eğitimde Kuram ve Uygulama, 10(2), 352-367.

Milli Eğitim Bakanlığı [MEB]. (2013). IIlköğretim kurumları (ilkokullar ve ortaokullar) fen bilimleri dersi $(3,4,5,6,7$ ve 8. sınıflar) ögrretim programı. Ankara: MEB.

Milli Eğitim Bakanlığı [MEB]. (2018). Fen bilimleri dersi öğretim programı (ilkokul ve ortaokul 3, 4, 5, 6, 7 ve 8. sinıflar). Ankara: MEB.

Özcan, H., \& Koca, E. (2019). STEM'e yönelik tutum ölçeğinin Türkçeye uyarlanması: Geçerlik ve güvenirlik çalışması. Hacettepe Üniversitesi Eğitim Fakültesi Dergisi, 34(2), 387-401.

Özkan, Ö., Tekkaya, C., \& Çakıroğlu, J. (2002, Ekim). Fen bilgisi aday öğretmenlerin fen kavramlarını anlama düzeyleri, fen ögretimine yönelik tutum ve öz yeterlik inançları. V. Ulusal Fen ve Matematik Eğitimi Kongresi, Ankara.

Schmid, S. (2015). Does inquiry-learning support long-term retention of knowledge? International Journal of Learning, Teaching and Educational Research, 10(4), 51-70.

Sever, D., \& Güven, M. (2012). İlköğretim fen ve teknoloji dersinde araştırma temelli öğrenme yaklaşımının öğrenci dirençlerine etkisi. Kuram ve Uygulamada Eğitim Bilimleri, 14(4), 1583-1605.

Simon, S., Erduran, S., \& Osborne, J. (2006). Learning to teach argumentation: Research and development in the science classroom. International Journal of Science Education, 28(2-3), 235260.

Spronken-Smith, R., Bullard, J. O., Ray, W., Roberts, C., \& Keiffer, A. (2008). Where mights and dunes be on Mars? Engaging students through inquiry-based learning in geography. Journal of Geography in Higher Education, 32(1), 71-86.

Şahin, E., \& Kabasakal, V. (2018). STEM eğitim yaklaşımında dinamik matematik programlarının (Geogebra) kullanımına yönelik öğrenci görüşlerinin incelenmesi. Anemon Muş Alparslan Üniversitesi Sosyal Bilimler Dergisi, 6(STEMES'18), 55-62.

Şaşmaz-Ören, F., Ormancı, Ü., Babacan, T., Çiçek, T., \& Koparan, S. (2010). Analoji ve araştırma temelli öğrenme yaklaşımına dayalı rehber materyal uygulaması ile buna yönelik öğrenci görüşleri. Batı Anadolu Eğitim Bilimleri Dergisi, 1(1), 33-53. 
Şenler, B. (2017). Fen bilgisi öğretmen adaylarının fen öğretimine yönelik öz-yeterlik inançları ile bilimsel sorgulamaya ilişkin görüşlerinin incelenmesi. Eğitim Kuram ve Uygulama Araştırmaları Dergisi, 3(2), 50-59.

Şensoy, Ö., \& Aydoğdu, M. (2008). Araştırma soruşturma tabanlı öğrenme yaklaşımının fen bilgisi öğretmen adaylarının fen öğretimine yönelik öz yeterlik inanç düzeylerinin gelişimine etkisi. Gazi Üniversitesi Gazi Eğitim Fakültesi Dergisi, 28(2), 69-93.

Tan, P. H., \& Tan, A. L. (2014). Teachers' ideas and concerns with assessment practices in inquiry science. A. L. Tan, A. L. Poon ve S. S. L. Lim (Ed.). Inquiry into the Singapore science classroom (pp. 67-87), Singapore: Springer.

Tatar, N. (2006). Illköğretim fen eğitiminde araştırmaya dayalı öğrenme yaklaşımının bilimsel süreç becerilerine, akademik başarıya ve tutuma etkisi. Yayınlanmamış doktora tezi, Ankara: Gazi Üniversitesi.

Tatlı, Z., Akbulut, H. İ., \& Altınışık, D. (2016). Öğretmen adaylarının teknolojik pedagojik alan bilgisi özgüvenlerine web 2.0 araçlarının etkisi. Turkish Journal of Computer and Mathematics Education, 7(3), 659-678.

Timur, B., \& Taşar, F. (2011). Teknolojik pedagojik alan bilgisi öz güven ölçeğinin (TPABÖGÖ) Türkçe'ye uyarlanması. Gaziantep Üniversitesi Sosyal Bilimler Dergisi, 10(2), 839 -856.

TUSIAD (2017). 2023'e doğru Türkiye'de STEM gereksinimi. Web: http://tusiad.org/tr/yayinlar/raporlar/item/9735-2023-e-dog-ru-tu-rkiye-de-stem-gereksinimi 26.03.2018'de alınmıştır.

Tümay, H., \& Köseoğlu, F. (2011). Kimya öğretmen adaylarının argümantasyon odaklı öğretim konusunda anlayışlarının geliştirilmesi. Türk Fen Eğitimi Dergisi, 8(3), 105-119.

Werner, R. J. (2007). Inquiry-based learning at Minnesota's University of St. Thomas. International Journal of Learning, 14(1), 51-56.

Wu, M. C., Marsono, M., \& Khasanah, F. (2019, January). Advancing vocational student's self-efficacy through integration STEM (science technology engineering and mathematics) education. In 2nd International Conference on Vocational Education and Training (ICOVET 2018). Atlantis Press.

Yaman, F. (2019). Öğrencilerin sanal kimya laboratuvarı kullanarak hazırladıkları argümantasyona dayalı yazma etkinliklerinin çoklu gösterimler açısından incelenmesi. Ilköğretim Online, 18(1), 207225.

Yaman, S., \& Yalçın, N. (2005). Fen eğitiminde probleme dayalı öğrenme yaklaşımının problem çözme ve öz-yeterlik inanç düzeylerinin gelişimine etkisi. Hacettepe Üniversitesi Eğitim Fakültesi Dergisi, 29(29), 229-236.

Yaman, S., Cansüngü Koray, Ö., \& Altunçekiç, A. (2004). Fen bilgisi öğretmen adaylarının öz-yeterlik inanç düzeylerinin incelenmesi üzerine bir araştırma. Türk Eğitim Bilimleri Dergisi, 2(3), 355-366.

Yener, D., Aydın, F., \& Köklü, N. (2012). Genel fizik laboratuvarındaki öğrencilerin fiziğe karşı özyeterliliklerine animasyon ve simulasyonun etkisi. Abant izzet Baysal Üniversitesi Eğitim Fakültesi Dergisi, 12(2) 121-136. 
Ümmühan Ormancı, Sevinç Kaçar, Erkan Özcan, A. Günay Balım - Uluslararası Eğitim Programlar ve Öğretim Çalışmaları Dergisi, 10(1), 2020, 1-28

Yıldırım, B., \& Altun, Y. (2015). STEM eğitim ve mühendislik uygulamalarının fen bilgisi laboratuar dersindeki etkilerinin incelenmesi. El-Cezeri Journal of Science and Engineering, 2(2), 28-40.

Yıldırım, B., \& Türk, C. (2018). Sınıf öğretmeni adaylarının STEM eğitimine yönelik görüşleri: uygulamalı bir çalışma. Trakya Üniversitesi Eğitim Fakültesi Dergisi, 8(2), 195-213.

Yıldırır, H. E., \& Nakiboğlu, C. (2014). Kimya öğretmen ve öğretmen adaylarının derslerinde kullandıkları argümantasyon süreçlerinin incelenmesi. Abant Izzet Baysal Üniversitesi Eğitim Fakültesi Dergisi, $14(2), 124-154$.

Yurdatapan, M. (2013). Probleme dayalı laboratuvar etkinliklerinin öğrencilerin bilimsel süreç becerilerine özgüvenine ve öz-yeterliliğine etkisi. Hacettepe Üniversitesi Eğitim Fakültesi Dergisi, Özel Sayı, 421-435. 